\title{
Türkiye'de Turizme Yönelik Kamu Teşvik Politikaları Çerçevesinde illerin Etkinlik Analizi
}

\author{
Sibel Aybarç ${ }^{1}$ \\ Sibel Selim² \\ Özlem Ayvaz Kızılgöl ${ }^{3}$
}

Türkiye'de Turizme Yönelik Kamu Teşvik Politikaları Çerçevesinde İllerin Etkinlik Analizi

Öz

Turizm sektörünün ülke ekonomisi açısından taşıdığı önem dolayısıyla devlet tarafından gerek vergisel teşvikler, gerek yasal düzenlemeler, gerekse sağlanacak istisna ve muafiyet uygulamaları ve sübvansiyonlarla desteklenmesi gerekmektedir. Bu çalışmanın amacı, uygulanan kamu teşvik politikaları kapsamında 2005-2015 yılları arasında Veri Zarflama Analizi kullanılarak Türk turizminde illerin teknik etkinliğini belirlemektir. Bu amaç doğrultusunda, çalışmada kullanılan girdi değişkenleri, il bazında turizm sektörüne yapılan yatırım teşvik belgesi sayısı, teşviklerle sağlanan sabit yatırımlar, istihdam, turizm amaçlı kullanılan ihtiyaç kredileri, illerde kamu hizmetlerine yapılmış olan harcamalar, turizm yatırım ve işletme belgeli tesis sayısı, oda sayısı, yatak sayısı ve çıktı değişkenleri ise toplam tesise geliş sayısı ile geceleme sayısıdır. Elde edilen bulgulara göre, Akdeniz ve Ege bölgesindeki illerin Doğu bölgelerine göre turizm açısından daha etkin olduğu belirlenmiştir.

Anahtar Kelimeler: Turizm Sektörü, Kamu Teşvik Politikaları, Turizme Yönelik Kamu Harcamaları ve Özel Harcamalar, Teknik Etkinlik, Veri Zarflama Analizi
Efficiency Analysis of the Provinces on the Basis of Public Incentive Policies for Tourism in Turkey

Abstract

Tourism sector in terms of the country's economy needs to be supported by the state with tax incentives, legal regulations, exceptions and exemption applications and subsidies. The aim of this study is to determine the technical efficiency of the provinces in Turkish tourism using Data Envelopment Analysis among 2005- 2015 depending on public incentive policies. For this purpose, input variables used in the study are the number of investment incentive certificates, fixed investments provided by incentives, employment, need loans, expenditures on public services, number of facilities with tourism investment and operation certificate, number of rooms and beds and output variables are total the number of arriving tourists and number of nights stay. According to the findings, it is determined that the provinces in the Mediterranean and Aegean regions are more effective than the Eastern regions in terms of tourism.

Keywords: Tourism Sector, Public Incentive Policies, Public Expenditures and Special Expenditures for Tourism, Technical Efficiency, Data Envelopment Analysis

\section{Giriş}

Belirli bir amaç doğrultusunda insanların ikametgahları dışında seyahat ve konaklama faaliyetlerinden oluşan ilişkiler bütünü olarak tanımlanan turizm, bilinenin aksine eski çağlara değin uzanmaktadır. Sümerler'de tekerlek, yazı, para ve ticaretin icadı; Fenikelilerde gezginlik felsefesi; Eski Yunan'da spor-turizm-din örgüsü çerçevesinde düzenlenen Olimpiyat Oyunları; Ortaçağ Avrupası'nda yaygınlaşan dini seyahatler; Osmanlı'da Evliya Çelebi seyahatleri; 17. ve 18. yüzyıl Avrupası'nda zengin aile çocuklarına yönelik eğitim seyahatleri turizmin yalnızca modern

\footnotetext{
${ }^{1}$ Dr. Öğr. Üyesi, Manisa Celal Bayar Üniversitesi, IïBF, Maliye Bölümü. sibel.aybarc. bursalioglu@gmail.com, Yazar ORCID bilgisi: http://orcid.org/0000-0002-9756-4923.

2 Prof. Dr., Manisa Celal Bayar Üniversitesi, iiBF, Ekonometri Bölümü. sibel.selim@cbu.edu.tr, Yazar ORCID bilgisi: http://orcid.org/0000-0002-8464-588X.

${ }^{3}$ Dr. Öğr. Üyesi, Bandırma Onyedi Eylül Üniversitesi, IiBF, Ekonometri Bölümü. okizilgol@bandirma.edu.tr, Yazar ORCID bilgisi: http://orcid.org/0000-0001-9996-7892.
} 
çağa özgü olmadığının birer kanıtıdır. Sanayi Devrimi'nin etkisiyle ekonomik anlam yüklenen turizm faaliyeti, gerek ulaşım olanaklarının, gerekse insanların boş zamanlarının artması sonucu ivme ve deniz-kum-güneş çerçevesinde yeni tür kazanmıştır (Bahar ve Kozak, 2013). Bilgi çağının getirisi bilgi ve iletişim teknolojilerine bağlı olarak kongre turizmi, uzay turizmi, temalı otel turizmi, doğa turizmi, kumar turizmi, av turizmi gibi farklı tercihlere göre şekillenen turizm türleri geliştirilmiştir.

Uluslararası rekabetin yoğun olduğu günümüz dünyasında yaşanan küresel krizler sonucu özellikle az gelişmiş ve gelişmekte olan ülkelerdeki tasarruf yetersizliği, ihracat olanaklarının sınırlı oluşu, dış borç miktarının hızla artışı ve sürdürülebilirlik sorunsalı karşısında turizm sektörü, önemli bir çözüm alternatifi olarak görülmektedir. Nitekim sektör, kalkınma için gerekli yatırımların kısa dönemde hızlı bir şekilde yapılmasını, yeni iş alanları ve istihdam olanakları artışını sağlamakta, böylece ülke ekonomisi açısından daha fazla önem arz etmektedir (Bahar ve Kozak, 2013).

Türkiye için turizm, özellikle 1980 sonrası önem arz eden bir sektör olmuştur. Bu süreç, 1980'li yılların başından itibaren uygulanan ihracat-odaklı ekonomi politikası, yabancı sermayenin teşviki, döviz alım-satımının serbestleşmesi ve Turizmi Teşvik Kanunu ile şekillenmiştir (Gül, 2013). 1982 tarih ve 2634 Sayılı Turizmi Teşvik Kanunu ile turizm sektörüne kredi ve yatırım kolaylıkları; vergi-resim-harç istisnaları; hazine ve orman arazilerinin turistik tesis yatırımlarına tahsisi; yabancı personel çalıştırılması ile ilgili kolaylıklar; KDV ertelemesi; çeşitli hizmetlerin öncelikli tahsisi; elektrik, gaz, su tarifelerinde indirim; çevreye duyarlı konaklama tesisi belgeli işletmelere elektrik enerjisi desteği; haberleşme kolaylıkları; yurtdışı turizm fuarlarına katılım desteği gibi teşvik ve destekler getirilmiştir. Yasal düzenlemeler çerçevesinde T.C. Kültür ve Turizm Bakanlığı verilerine göre, 1980 'de 1.2 milyon civarında olan turist sayısı 2014 yılında 36.8 milyona yükselmiştir. 2015 yılında yaşanan olumsuz gelişmeler sonucu 36.2 milyona, 2016 yılında ise 25.3 milyona gerileyen turizm sektörüne yönelik güncel teşvik ve destekler getirilmiştir. Yeni düzenlemeler sonucu, ilk altı aylık toplam turist sayısı son üç yıl itibari ile karşılaştırıldığında, 2015 'te 14.8 milyon, 2016 'da 10.7 milyon, 2017'de 12.2 milyon düzeyi görülmektedir. 2016 yılında 2015 yılına nazaran \%27,8 oranında gerileyen turist sayısında, 2017 yılında 2016 yılına nazaran \% 14 oranında artış olduğunu göstermektedir.

Turizm hacmi, turist sayısına bağlı olarak turizm gelirini de belirlediği için ekonomik büyüme ve kalkınma açısından önem arz etmektedir. Nitekim, Birleşmiş Milletler Dünya Turizm Örgütü (The United Nations World Tourism Organization - UNWTO), 2017 yılını uluslararası "Kalkınma İçin Sürdürülebilir Turizm Yılı" ilan ederek, turizmin ekonomik, sosyal ve kültürel sürdürülebilirliği sağlamak suretiyle gerek ulusal, gerekse uluslararası arenada önemini vurgulamıştır. Sürdürülebilir turizm, gelecek nesillere bırakılacak çevresel ve kültürel miras gözetilip korunarak, günümüz dünyasındaki turistler ile ev sahipliği yapan bölge halkının ihtiyaçlarının karşılanmasıdır. Dünya Turizm Örgütü, 2017 Uluslararası Kalkınma İçin Sürdürülebilir Turizm Yılı'nın hükümetler, ilgili Birleşmiş Milletler örgütleri, uluslararası ve bölgesel organizasyonlar ile diğer tüm paydaşların işbirliği içerisinde organize edilmesi ve çeşitli turizm faaliyetinde bulunulmasını talep etmektedir (UNWTO, 2015). Bu çerçevede çalışma, kalkınma için sürdürülebilir turizmin önemi ve turizme yönelik kamu teşvik politikaları çerçevesinde sosyal ve ekonomik göstergelere göre Türkiye'de illerin turizm açısından etkinlik düzeylerini tespit etmeyi amaçlamaktadır.

Çalışmanın izleyen bölümleri şu şekildedir. İkinci bölümde Türk turizm sektörünün sosyoekonomik boyutu ele alınmıştır. Üçüncü bölümde turizm sektörüne yönelik kamu teşvik politikaları sunulmuştur. Literatür araştırmasının olduğu bölüm dördüncü bölümdür. Beşinci bölümde 
Veri Zarflama Analizi (VZA) tanıtılmıştır. Altıncı bölümde çalışmada ele alınan VZA kullanılarak, elde edilen etkinlik sonuçları verilmiştir. Yedinci bölüm ise genel değerlendirmenin yapıldığı sonuç bölümüdür.

\section{Turizm Sektörünün Sosyo-Ekonomik Boyutu}

Sürdürülebilir kalkınmanın kültürel, çevresel, sosyal, siyasi ve ekonomik boyutlarını kapsayan turizm sektörü (T.C. Kalkınma Bakanlığı, 2014), çok boyutlu bir olgu olarak karşımıza çıkmaktadır. Sürdürülebilir turizmin siyasi çıkarımları ekonomik uygulanabilirlik, yerel refah, toplumsal refah, istihdam, sosyal eşitlik, turist memnuniyeti, yerel kontrol, kültürel zenginlik, fiziki bütünlük, bio-çeşitlilik, kaynak etkinliği çerçevesinde şekillenmektedir (UNEP, 2005).

$\mathrm{Bu}$ açıdan ele alındığında turizm, bireysel tercihlere bağlı olmakla birlikte, birbirinden farklı sektörler ile ekonomik, siyasi, sosyal, hukuki ve çevresel faktörlere dayanan ulusal ve uluslararası ekonomik bir harekettir. Şöyle ki, bir bölgede yaşanan bir savaş veya terör olayı, finansal piyasalarda oluşan dalgalanmalar, ülkelerarası boyutta meydana gelen bir kriz veya bir çevresel afet o bölgeye yönelik turizm talebinin azalmasına neden olmaktadır. Diğer ülkelerde olduğu gibi Türk turizm sektörü de bölge, ülke ve dünya genelindeki gelişmelerin etkisi altında şekillenmektedir. Gerek yurt içinde 1990'lı yıllarda yoğunlaşan PKK terörü, 1999'da yıkıcı etki bırakan büyük Marmara depremi, 2000-2001 yıllarında yaşanan finansal kriz, 2015 yılında Rusya ile yaşanan siyasi kriz ile 2016 yılında yaşanan darbe girişimi; gerekse 1991'de yaşanan Körfez Savaşı, 1998 yılında Asya ülkeleri ve Rusya'da meydana gelen ekonomik kriz, 2008'de Amerika'da başlayıp tüm dünyayı etkileyen Mortgage Krizi ülkeye gelen turist sayısını ve buna bağlı olarak turizm gelirini etkilemiş̧ir (Gül, 2013). Farklı sosyal ve kültürel yapıdaki toplumlar arasında etkileşim sağlayan turizm sektörü sosyal yapıda değişime de yol açabilmektedir. Bu süreç, insan gruplarının, demografik ve kültürel özelliklerin, gelenek ve göreneklerin, yaşam şekillerinin, değer yargılarının, folklorların bir bütün olarak ele alınıp değerlendirilmesini gerektirmektedir (Civelek, 2010).

Turizm, kişiye sağladığı sosyal, kültürel ve psikolojik etkilerinin yanı sıra ekonomik anlamda da önemli etkiye sahip bir faaliyettir. Sektörde üretilen mal ve hizmetler faaliyetin arz yönünü, bunların turistler tarafından rağbet görmesi ise talep yönünü oluşturmaktadır. Tüm mal ve hizmetler gibi turizm ürünü/hizmeti de üretimden tüketime kadar ekonomik olarak üretim, pazarlama, dağıtım, satış, tüketim aşamalarına konu olmaktadır. Bunun yanı sıra sektör, ulaşım, haberleşme, konaklama, bankacılık, yeme-içme, eğlence, sağlık, eğitim gibi çok sayıda sektör ile etkileşim halindedir. Turizm sektörü, ekonomide faaliyet gösteren diğer sektörlerden mal ve hizmet satın alarak, turizm ürününü/hizmetini bir bütün olarak turistlere sunmaktadır (Bahar ve Kozak, 2013). Bu açıdan turizm sektörü, dünyanın en büyük ticaret kategorileri arasında yer almaktadır. Ülkelerin ihracat gelirlerinde önemli yere sahip olan turizm, genel mal ve hizmetler ihracatının \% 6'sını temsil etmektedir (T.C. Kalkınma Bakanlığı, 2014).

Turist sayısına bağlı olarak ülke ekonomisinin hemen her sektörünü ilgilendiren turizm sektörü, sağladığı doğrudan ve dolaylı katkılar sonucu ekonomik arenada oldukça önemli etkiye sahiptir. Ulaşım, haberleşme, konaklama, eğlence, yeme-içme sektörlerinin nihai ürün ve hizmet satışları sektörün ekonomiye doğrudan katkısını oluştururken; bu sektörlerin yaptığı tedarikçi alımları, yeni yatırımlar, sektörel harcamalar ile kamu harcamaları ekonomiyi dolaylı yönden etkilemektedir. İlgili sektörde çalışan kişilerin yaptıkları bireysel harcamalar ise uyarılmış tüketim etkisi göstererek, ekonomi üzerinde etki meydana getirmektedir (World Travel and Tourism Council, 2017; Sarsın Kaya, 2017). Şöyle ki; turizm faaliyetinin gelişimi sonucu sektör ça- 
Iışanlarının gelirlerinde artış meydana gelmekte, bu artışa bağlı olarak sektör çalışanlarının konut, gıda, giysi, dayanıklı tüketim malzemesi, taşıt gibi mal ve hizmetlere yönelik talebinde artış, dolayısıyla ekonomi üzerinde uyarılma sonucu bir etki görülmektedir.

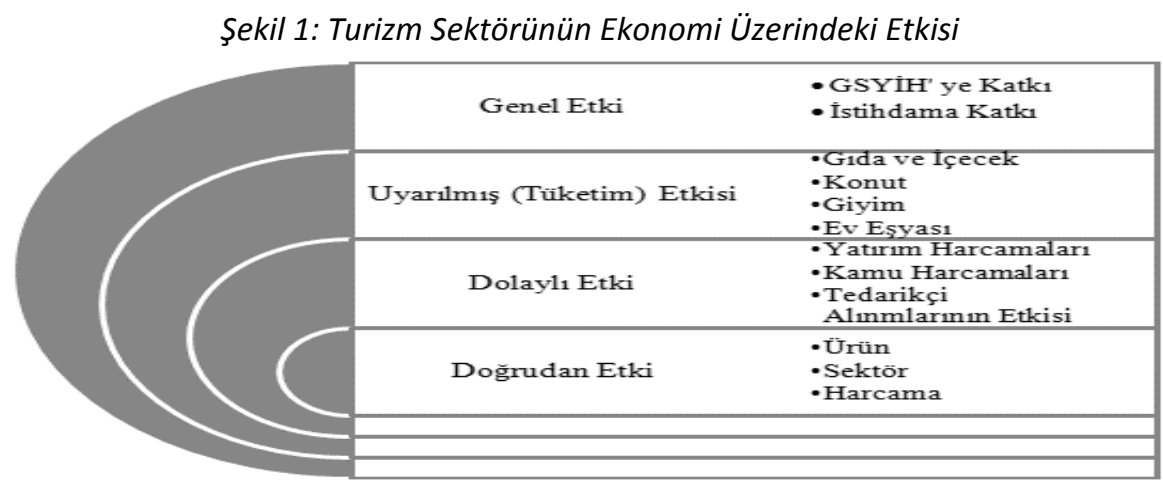

Kaynak: World Travel and Tourism Council, 2017; Sarsın Kaya, 2017. (Yazarlar tarafından yeniden düzenlenmiştir)

Dünya Seyahat ve Turizm Konseyi (World Travel and Tourism Council - WTTC) 2017 yılı Seyahat ve Turizmin Ekonomik Etkisi Türkiye Raporu kapsamında, turizmin GSYiH'ye katkısını doğrudan, dolaylı ve uyarılmış katkı olmak üzere Tablo 1'de görüldüğü gibi yayınlamıştır. 2017 yılında turizmin GSYH'ye doğrudan katkısı 89.7 milyar TL, dolaylı katkısının 125.2 milyar TL olacağı tahmin edilmektedir. 2027 yılında ise GSYH'ye doğrudan katkısı 144.3 milyar TL, dolaylı katkısının 182.4 milyar TL olacağı öngörülmektedir. Aynı rapor çerçevesinde, 2016 yılında 495 bin olan Türk turizminin istihdama doğrudan katkısının, 2017 yılında 484 bin, 2027 yılında ise 797 bin olacağı tahmin edilmektedir. Rapor kapsamında ayrıca, Türk turizminin istihdama toplam katkısı 2016 yılında 2.197 .500 olarak gerçekleşirken, 2017 yılında 2.118.500 ve 2027 yılında ise 2.967.000 düzeyine ulaşacağı öngörülmektedir.

Tablo 1: Türk Turizminin GSYiH Üzerine Katkısı (Milyar TL)

\begin{tabular}{ccccc}
\hline Yıl & $\begin{array}{c}\text { Turizmin GSYiH'ye Doğ- } \\
\text { rudan Katkısı }\end{array}$ & $\begin{array}{c}\text { Turizmin GSYiH'ye } \\
\text { Dolaylı Katkısı }\end{array}$ & $\begin{array}{c}\text { Turizmin GSYiH Üze- } \\
\text { rindeki } \\
\text { Uyarılmış Katkısı }\end{array}$ & $\begin{array}{c}\text { Turizmin } \\
\text { GSYiH'ye } \\
\text { Toplam KatkıSı }\end{array}$ \\
\hline 2011 & 80.8 & 103.9 & 46 & 230.7 \\
2012 & 83.5 & 99.9 & 46.1 & 229.5 \\
2013 & 90.4 & 112.1 & 50.5 & 253.0 \\
2014 & 96.9 & 125.2 & 55.4 & 277.2 \\
2015 & 100.6 & 128.5 & 57.8 & 286.9 \\
2016 & 87.9 & 124 & 53.8 & 265.7 \\
$2017^{*}$ & 89.7 & 125.2 & 53.5 & 268.4 \\
$2027^{*}$ & 144.3 & 182.4 & 84.6 & 411.3 \\
\hline
\end{tabular}

Kaynak: World Travel and Tourism Council, 2017. * Tahmini

Dünya Seyahat ve Turizm Konseyi raporu kapsamında, 2016 yılı turizm sektörünün GSYiH'ye doğrudan katkısı \%4,1; dolaylı ve uyarılmış tüketim etkilerinin de dahil edilmesiyle bu oran \%12,5 düzeyinde gerçekleşmektedir. Rapora göre, 2027 yılında bu oranların sırasıyla \%4,8 ile \%13,8 düzeyine ulaşacağı öngörülmektedir. Yine rapor kapsamında, 2016 yılı turizm sektöründe çalışanların toplam istihdam içindeki payı \%1,8; sektöre kaynak sağlayan yatırımcı, devlet ve tedarikçi gibi mal ve hizmet sunan aktörlerin çalışanları göz önüne alındığında turizm sektörünün istihdama yönelik toplam katkısı \%8,1 düzeyinde gerçekleşmektedir. Rapora göre, 2027 yılında bu oranların sırasıyla \%2,6 ile \%9,5 düzeyine ulaşacağı öngörülmektedir (World Travel and Tourism Council, 2017). 


\section{Türk Turizm Sektörüne Yönelik Kamu Teşvik Politikaları}

Turizm sektörü alt yapısı, gerek istikrarlı bir ekonomik ortam sağlamak, gerekse plan ve program öncelikleri çerçevesinde teşvik ve destek politikaları ile sektörü yönlendirmek amacıyla kamu kesimi tarafından şekillendirilmektedir. Hatta Onuncu Beş Yıllık Kalkınma Planı kapsamında, ülke ekonomisi açısından önemli kaynak sağlayan turizm sektörü, aynı zamanda bölgeler arası gelir ve gelişmişlik dengesizliklerinin giderilmesinde önemli bir araç olarak gösterilmektedir. Turizm sektörü gerek bölgesel, gerek ulusal, gerekse uluslararası taşıdığı önem dolayısıyla her zaman kamu teşvik ve destek politikalarına gereksinim duymaktadır.

Türk turizmine yönelik teşvik sistemi incelendiğinde, 1950 tarih ve 5647 Sayılı Turizm Müesseseleri Teşvik Kanunu ile hangi işletmelerin "turizm müessesesi" olacağı, teşvik uygulamalarından hangi işletmelerin faydalanacağı, teşviklerden faydalanma koşulları ile turizm işletmelerinin denetlenmesine ilişkin; 1953 tarih ve 6086 Sayılı Turizm Endüstrisini Teşvik Kanunu ile turizm yatırımlarının on yıl süre ile vergi muafiyetinden faydalanacağına ilişkin düzenlemelerin yer aldığı görülmektedir. Ardından 1980 tarih ve 8/1133 Sayılı Turizm Teşvik Çerçeve Kararı ile yatırımların yoğunlaştırılacağı alanların planlanması, yeni finansal kaynakların tespiti, yabancı yatırımcıların özendirilmesi, turizm yatırımlarının teşvikine ilişkin esasların geliştirilmesi amacıyla Turizm Koordinasyon Kurulu tesis edilmiştir (Toker, 2007). Turizm sektörünün günümüze kadar gelen ivmesi, 1982 tarih ve 2634 Sayılı Turizm Teşvik Kanunu ile gerçekleşmiştir. Söz konusu düzenleme ile turizmde öncelikli bölgeler ${ }^{4}$ "Turizm Alan ve Merkezleri" haline getirilerek, bu alanlarda yer alan hazine ve orman arazilerinin ${ }^{5}$ yatırımcıya tahsisi sağlanmıştır. Ayrıca Kanun ile turizm sektörüne ilişkin yabancı personel çalıştırılması ile ilgili kolaylıklar, deniz turizmi ile ilgili kolaylıklar, elektrik, gaz, su tarifelerinde indirim, haberleşme kolaylıkları, orman fonuna katkının taksitlendirilmesi, yurtdışı turizm fuarlarına katılım desteği gibi teşvik ve destekler getirilmiştir.

1985 yııında turizm sektörünün "Kalkınmada Özel Önem Taşıyan Sektör" kapsamına alınarak, teşviklerin arttırılması ve çeşitlendirilmesi turizm amaçlı yatırım sayısını arttırmıştır. 1990 Körfez Savaşı turizmi sekteye uğratsa da bu süreçte uygulanan teşvikler ile sektör ivme kaydetmiştir. 1985-1999 uygulanan teşvik tedbirleri gümrük muafiyeti, yatırım indirimi, özel önem taşıyan sektör ile Kalkınmada Öncelikli Yörelerde çalışanların ücretlerinin vergilendirilmesinde indirim, yatırım finansman fonundan yararlanma, bina inşaat harcı istisnası, vergi-resim-harç istisnası, döviz tahsisi, konut inşaatında vergi-resim-harç istisnası ve muafiyetleri (örn; turizm işletmeleri 5 yıl süre ile Emlak Vergisi'nden muaftır), faiz farkı indirimi, Kaynak Kullanımını Destekleme Primi-Teşvik Primi-yatırım malı imalatçısı teşvik kredisi, rıhtım resmi muafiyeti, KDV ertelemesi, ithal hakkı, ulaştırma altyapıları resmi muafiyeti, teşvik kredileri, SSK zorunlu tasarruf, Konut Edindirme Fonu ve Enerji Teşviki, arsa ve arazi tahsisi, ilave istihdam teşviki şeklinde sıralanabilir (Önen, 2000).

Günümüz turizm yatırımcıları daha önceleri sağlanan kredi ya da borç alma gibi finansal teşviklere nazaran, vergi teşviklerini esas alan "Genel Teşvik Sistemi'nden yararlanmaktadır. Bu noktada genel olarak Türk turizm sektörüne yönelik devlet teşvikleri, aşağıdaki gibi özellikli dönemlere ayrılarak özetlenebilir (T.C. Kalkınma Bakanlığı, 2014):

\footnotetext{
${ }^{4} 1969$ tarih ve 6/12209 Sayılı KHK ile Çanakkale ili güney sınırı ile İçel ili batı sınırı arasında kalan kıyı bölgesi "turizmde öncelikli bölge" olarak belirlenmiştir.

${ }^{5}$ Kamu arazilerinin turistik konaklama tesisi yatırımları için en fazla 49 yıllığına, kamping yatırımları için en fazla 20 yıllığına tahsisi söz konusudur.
} 
*1985-1991 yılları arası dönemi kapsayan "Kaynak Kullanımı Destekleme Primli Dönem"

*1991-1992 yılları arası dönemi kapsayan "Kaynak Kullanımı Destekleme Fonu Kaynaklı Kredi Dönemi"

*1992-1994 yılları arası dönemi kapsayan "Fon Kaynaklı Kredi Dönemi"

*1995-2009 yılları arası dönemi kapsayan "Genel Teşvik Sistemi Dönemi"

*2009-2011 yılları arası dönemi kapsayan "Bölgesel - Sektörel Teşvik Sistemi, Büyük Proje Teşvik Sistemi, Genel Teşvik Sistemi" olmak üzere üç ana bileşenden oluşan Dönem

*2011 yılından itibaren süregelen "Bölgesel - Sektörel Teşvik Sistemi, Büyük Proje Teşvik Sistemi, Genel Teşvik Sistemi, Stratejik Yatırımların Teşviki" olmak üzere dört ana bileşenden oluşan Dönem (il Bazlı Bölgesel Teşvik sistemi kapsamında gelişmişlik düzeyine göre belirlenen altı bölgede, turizm yatırımlarına destek sağlanmaktadır.)

2634 Sayılı Turizmi Teşvik Kanunu kapsamındaki desteklerin yanı sıra turizm sektörü acil eylem planı destekleri, turizm sektörüne yönelik istihdam destekleri, turizm işletme belgeli tesislere sağlanan avantajlar ile diğer kamu kurumları tarafından sağlanan destekler de bulunmaktadır. Turizm sektörü acil eylem planı destekleri kapsamında (T.C. Kültür ve Turizm Bakanlı̆ıı);

Eylem 1: Türkiye'ye turist getiren (A) grubu seyahat acentalarına uçuş başına 6.000 USD destek verilmesi. 200 ve daha fazla koltuk sayısına sahip uçaklarda en az 150 yolcu getirilmesini sağlayan (A) grubu seyahat acentalarına 6.000 USD destek miktarı \% 30 arttırılacaktır.

Eylem 2: Kredi başvuru tarihinden bir önceki yıl seçilmiş ülkelerden ${ }^{6}$ en az 400.000 turisti Türkiye'ye getiren ve Kültür ve Turizm Bakanlığı'ndan belgeli Türkiye Seyahat Acentaları Birliği üyesi (A) grubu seyahat acentelerine Kredi Garanti Fonu teminatı ile 100.000.000 TL'ye kadar kredi kullanma imkanı sağlanmıştır.

Eylem 3: Bankacılık Düzenleme ve Denetleme Kurumu tarafından "Karşılık Yönetmeliği Uygulamasına iliş̧kin Kurul Kararı" alınması ve "Bankalarca Kredilerin ve Diğer Alacakların Niteliklerinin Belirlenmesi ve Bunlar İçin Ayrılacak Karşılıklara İlişkin Usul ve Esaslar Hakkında Yönetmelikte Değişiklik Yapılmasına Dair Yönetmelik" ile turizm sektörüne kolaylık sağlanmıştır. Bu kapsamda donuk alacaklar (krediler) iki defa ile sınırlı olmak üzere yeniden yapılandırılabilecek; ilk yeniden yapılandırmada gecikmiş tutarların ödenmiş olması ve sınıflandırma tarihinden önceki son üç ödemenin zamanında yapılmış olması kaydıyla donuk alacak canlı olarak sınıflandırılabilecek; ikinci yeniden yapılandırma için gecikmiş ödemelerin zamanında yapılması ve sınıflandırma tarihinden önceki son altı ödemenin zamanında yapılmış olması gerekecektir.

Eylem 4: Kültür ve Turizm Bakanlığından belgeli deniz turizmi tesislerine yeni yatırım veya tesis yenileme işlemlerinde, bulundukları bölge teşviklerinden konaklama tesisleri gibi faydalanma imkanı sağlanmıştır.

Eylem 5: Kültür ve Turizm Bakanlığından belgeli konaklama tesisleri ile deniz turizmi tesislerinden bir önceki yıl 750.000 \$ döviz getiren yatırımcılar ihracatçı olarak kabul edilmiştir. Böylelikle ilgili yatırımcılar, Eximbank kredileri, bankalarda kredi işlemlerinde kolaylık, yurtdışı fuarlara katılım desteği, resim ve harçlardan muaf tutulma gibi desteklerden faydalanma imkanı bulmuşlardır.

\footnotetext{
${ }^{6}$ Azerbaycan, Belarus, Kazakistan, Kırgızistan, Özbekistan, Rusya Federasyonu, Türkmenistan, Ukrayna, Almanya, Avusturya, Belçika, Danimarka, Finlandiya, Fransa, Hollanda, İngiltere, İrlanda, İsveç, İsviçre, İtalya, Çek Cumhuriyeti, Polonya, Macaristan, Norveç, Bulgaristan, Romanya.
} 
Eylem 6: Kültür ve Turizm Bakanlığından belgeli turizm tesisi yatırımcıları ile işletmecilerinin Hazine taşınmazlarını izinsiz kullanmaları dolayısıyla 01.01.2016-31.12.2016 tarihleri arasındaki dönemde tahsil edilmesi gereken ecri misillerin ödeme sürelerinin başvuru şartı aranmaksızın bir yıl ertelenmesi kolaylığı sağlanmıştır. Ertelenen alacakların ilgili süre sonundan itibaren üç yılda üç eşit taksitle herhangi bir zam veya faiz uygulanmadan tahsil edilmesi öngörülmüştür.

Eylem 7: Konaklama amaçlı turizm tesisi yapılmak üzere adlarına kamu arazisi tahsis edilen Kültür ve Turizm Bakanlığından belgeli yatırımcılar ve işletmecilerin 01.01.2016 - 31.12.2016 tarihleri arasında ödemeleri gereken kira, kesin izin, kesin tahsis, irtifak hakkı, kullanma izni bedelleri ödeme sürelerinin başvuru şartı aranmaksızın bir yıl ertelenmesi kolaylığı sağlanmıştır. Ertelenen alacakların, bu sürenin sona erdiği tarihten itibaren üç yılda ve üç eşit taksitle herhangi bir zam veya faiz uygulanmadan tahsil edilmesi öngörülmüştür.

Eylem 8: Konaklama amaçlı turizm tesisi yapılmak üzere adlarına kamu arazisi tahsis edilen Kültür ve Turizm Bakanlığından belgeli yatırımcılar ve işletmecilerin 01.01.2016-31.12.2016 tarihleri arasında ödemeleri gereken hasılat paylarının ödeme sürelerinin başvuru şartı aranmaksızın bir yıl ertelenmesi kolaylığı sağlanmıştır. Ertelenen alacakların, bu sürenin sonundan itibaren üç yılda ve üç eşit taksitle herhangi bir zam veya faiz uygulanmadan tahsil edilmesi öngörülmüştür.

Turizm işletmeleri, 1319 Sayılı Emlak Vergisi Kanunu'nu uyarınca turizm müessesesi belgesi aldıkları yılı takip eden bütçe yılından itibaren 5 yıl süre ile Emlak Vergisi'nden muaf tutulmakta; 2464 Sayılı Belediye Gelirleri Kanunu'nun ilgili maddeleri uyarınca bina inşaat harcı ödememektedirler. Yine 99/13813 Sayılı İhracat, İhracat Sayılan Satış ve Teslimler ile Döviz Kazandırıcı Hizmet ve Faaliyetlerde Vergi, Resim ve Harç İstisnası Hakkında Karar ile 2008/6 Sayılı İhracat, Transit Ticareti ihracat Sayılan Satış ve Teslimler ile Döviz Kazandırıcı Hizmet ve Faaliyetlerde Vergi, Resim ve Harç İstisnası Hakkında Tebliğ uyarınca ihraç ürünlerine uluslararası piyasalarda rekabet gücü kazandırarak, ihracatı arttırmak amacıyla ihracat, ihracat olarak kabul edilen satışlar ve teslimler ile döviz kazandırıcı hizmet ve faaliyetlerde vergi, resim ve harç istisnası uygulanmaktadır. 4250 Sayılı İspirto ve İspirtolu İçkiler İnhisarı Kanunu gereğince Turizm İşletme Belgesi ile Turizm Yatırımı Belgesi ayrımı yapılmaksızın, Turizm Belgeli tesisler mesafe şartı veya işyeri açma ve çalışma ruhsatı aranmaksızın turizm belgeleri ile alkollü içki satış iznine sahip olmaktadırlar (T.C. Kültür ve Turizm Bakanlığı).

Tüm bu teşvik ve desteklere ek olarak turizm işletmeleri, Ekonomi Bakanlığı tarafından sağlanan Yatırım Teşvik Sistemi; sağılı turizmi kapsamında Acenta Komisyon Desteği, Reklam, Tanıtım ve Pazarlama Desteği, Bireysel Fuar Katılım Desteği, Ürün/Hizmet Tescil Desteği (T.C. Ekonomi Bakanlığı); özellikle 2009 tarihinden itibaren Küçük ve Orta Ölçekli İşletmeleri Geliştirme ve Destekleme İdaresi (KOSGEB) tarafından konaklama ve yiyecek faaliyetleri kapsamında sunulan desteklerden faydalanmaktadır.

\section{Turizmde illerin Etkinliği: Literatür Araştırması}

Türkiye' de turizm sektöründe faaliyet gösteren farklı bölgelerdeki konaklama işletmelerinin veya borsada turizm sektöründe yer alan konaklama işletmelerinin etkinlik analizlerini ölçmeye çalışan birçok araştırma bulunmaktadır. Genel olarak literatüre bakıldığında aynı alanda yapılmış çok sayıda çalışma mevcuttur. Bu çalışmalardan bazıları şunlardır:

Emir ve Özgür (2008), Akdeniz ve Ege bölgesinde 2004-2006 yıllarında mevcut konaklama işletmelerinin etkinlik analizini gerçekleştirmişlerdir. Konaklama tesisi yönünden en yoğun ilçeleri (Alanya, Kemer, Manavgat, Serik, Side, Bodrum, Fethiye, Marmaris, Kuşadası, Didim, Çeşme 
ve Selçuk) seçmişlerdir. VZA yardımıyla daha az yatak kapasitesine sahip bölgelerin etkin olmadığını, daha çok yatak kapasitesine sahip turizm bölgelerinin daha etkin olduğunu saptamışlardır. 2004 yılı etkinlik değerlerinin en yüksek olduğu yıl olurken, 2005 yılında etkinlik değerinde kısmi düşüş yaşanmış ve 2006 yılında etkinlik değerleri genel olarak artış göstermiştir. Erciş ve Gülcü (2008), Doğu Anadolu Bölgesindeki konaklama işletmeleri üzerinde bir çalışma yapmışlardır. Yaptıkları çalışmada, konaklama işletmelerinin göreceli hizmet üretim etkinliklerini VZA kullanarak ölçmüşlerdir. Sonuç olarak da hizmette aksayan veya etkin hizmet üretemeyen birimleri belirleyerek, çözüm önerileri sunmuşlardır. Özcan ve Babacan (2009), çalışmalarında Alanya bölgesinde faaliyette bulunan 22 otel işletmesinin etkinliğini VZA yardımıyla ölçmüşlerdir. Birbirlerine göre göreli etkinliklerini belirlerken Frontier Analyst programını kullanmışlardır. Analizde girdi yönelimli ve çıktı yönelimli CCR ve BCC modellerini uygulamışlardır. Girdi ve çıktılara ait veriler üzerinden 13 otelin etkin ve 9 otelin etkin olmadığını belirlemişlerdir. Bi, Luo ve Liang (2011) Çin turizm endüstrisinin etkinliği üzerinde odaklanıp, etkinsizliğini tanımlamayı ve gelişmelere bakış açısı sağlamayı amaçlamışlardır. Çin'de 31 il, ilçe ve özerk bölgenin etkinliklerini karşılaştırmak için iki aşamalı VZA modeli formüle etmişlerdir. Sonuçlar, Çin'de bölgesel turizmin düşük düzeyde gelişme gösterdiğini ve farklı bölgeler arasında büyük etkinlik farklılıkları olduğunu göstermiştir.

Benli (2012), 2007-2010 dönemini kapsayan çalışmasında Ege, Batı Marmara, Doğu Marmara ve Akdeniz bölgesindeki illerin teknik etkinlik, teknik etkinlikteki değişme, teknolojik değişim ve toplam faktör verimliliği ile bileşenlerindeki değişmelerin ölçümünü amaçlamıştır. Bu amaç doğrultusunda konaklama işletmelerinin verilerini kullanmıştır. VZA ve Malmquist Toplam Faktör Verimliliği Endeksi (MTFVE) yöntemlerinden yararlanarak, Akdeniz ve Ege bölgesinde yer alan illerdeki konaklama işletmelerinin Batı ve Doğu Marmara bölgesindekilere göre turistik açıdan zengin ve gelişmiş olduğunu bulmuş, diğer taraftan ortalama teknik etkinlik değerlerine göre hiçbir ilin ve konaklama işletmesinin etkin olmadığı sonucuna ulaşmıştır. Zengin, Çömlekçi ve Mesci (2013), Türkiye'de iMKB'de yer alan turizm işletmelerinin 2009-2010 yıllarına ilişkin mali verilerini kullanarak, finansal etkinliklerini ölçmek amacıyla VZA'den faydalanmışlardır. Belirlenen kriterlere göre etkin ve etkin olmayan turizm işletmelerini tespit etmişlerdir. Çalışma sonucunda dokuz adet turizm işletmesinin yedisinin etkin olduğu sonucuna ulaşmışlardır. Etkin olmayan turizm işletmelerinin etkin olamama nedenlerini araştırmışlardır.

Anumat ve Saosaowapak (2013) çalışmalarında 2001-2010 yılları için panel veri kullanarak stokastik sınır modeli yardımıyla uluslararası turizm gelirlerindeki değişimi etkileyen faktörleri belirlemişler ve Malezya, Tayland ve Singapur'da turizm sektörünün teknik etkinliğini ortaya koymayı amaçlamışlardır. Uluslararası turizm gelirlerinin değişimini etkileyen önemli faktörleri; arz edilen koltuk kilometre (available seat kilometer), hükümetin ulaşım ve telekomünikasyon harcamaları, sağlık tesislerindeki değişimin yüzdesi, hükümetin sosyal güvenlik ve refah harcamaları olarak belirlemişlerdir. Malezya, Tayland ve Singapur'da turizm sektörünün ortalama teknik etkinlik düzeyini 1.09 bulmuşlardır. Turizmde en yüksek teknik etkinliğe Malezya'nın sahip olduğu, Singapur'un ikinci, Tayland'ın üçüncü sırada yer aldığı sonucuna ulaşmışlardır. Oliveira, Pedro ve Marques (2013), VZA yardımıyla Portekiz'in Algarve bölgesindeki otellerin golf kursu verip vermemelerine göre etkinliğini karşılaştırmışlardır. 4 ve 5 yıldızlı otellerde, otellerin yıldız faktörünün, golf kursunun ve otelin konumunun onların etkinliği üzerindeki etkisini ölçmüşlerdir. Otelin yıldız faktörü etkinliğin önemli bir belirleyicisi değil iken, otelin konumu ve golf kursunun bulunması belirleyici olabilmektedir. Ayrıca çalışma sonucunda, 5 yıldızlı otellerin 4 yıldızlı otellere göre daha etkin olduğu ve yine golf kursu veren otellerin vermeyen otellere göre 
daha etkin olduğu tespit edilmiştir. Uyar ve Alış (2014), 2013 yılında Alanya'da faaliyet gösteren 37 konaklama işletmesinin faaliyet etkinliklerini VZA ile belirlemeye çalışmışlardır. Analiz sonucunda sadece 5 konaklama işletmesinin faaliyetlerinde etkin olduğunu tespit etmişlerdir.

Karakaya, Kurtaran ve Dağlı (2014), 2011 yılı sonu itibariyle Türkiye'deki 14 bireysel emeklilik şirketinin VZA ile etkinliklerini ölçmüşlerdir. Analiz sonucunda bu şirketlerden üçünü ölçeğe göre sabit getiri varsayımına göre etkin bulurlarken, ölçeğe göre değişken getiri varsayımına göre dokuzunu etkin olarak tespit etmişlerdir. Ölçeğe göre sabit getiri hesaplamasında etkinsiz şirket sayısının daha fazla olmasının nedenini, şirketlerin optimal olmayan ölçekte çalışmasına bağlamışlardır. Chien (2014) VZA yardımıyla Tayvan'daki turist otellerinin çalışma etkinliğini araştırmayı ve ülkenin farklı alanlarında onların etkinliğini karşılaştırmayı amaçlamıştır. En önemli sonuç olarak, bütün otellerin teknik etkinliğinin 2009 yılında en yüksek seviyede olduğunu bulmuştur. Shieh, Hu ve Gao (2014), Tayvan'daki uluslararası turist otellerinin maliyet etkinliği üzerinde turistlerin milliyetlerinin etkilerini ve bir turistin bir oteli seçmesini etkileyen faktörleri analiz etmişlerdir. 1998-2007 döneminde Tayvan'daki 61 uluslararası otelin maliyet etkinliğini hesaplamak için VZA yöntemini kullanmışlardır. Asyalı, Kuzey Amerikalı, Japon ve yerli turistlerin sayısının maliyet etkinliği üzerinde önemli bir pozitif etkiye sahip olduğunu, Çin'e deniz aşırı ülkelerin sayısının negatif etkiye sahip olduğunu bulmuşlardır. Diğer milliyetlere ait turistlerin sayısı ise maliyet etkinliğini etkilememektedir. Ayrıca genellikle Tayvan'daki turistlerin çoğunun daha büyük, daha eski ve hava alanına daha yakın otelleri tercih ettiği sonucuna ulaşmışlardır. Toma (2014), Romanya'da 2012 yılında turizm sektöründe faaliyet gösteren çeşitli otel ve restoranların finansal performanslarına bakarak, VZA ile bölgelerin turistik etkinlik analizlerini yapmıştır. Çalışma sonucunda, Romanya'nın kuzeybatı ve kuzeydoğu bölgelerinin, güneydoğu ve bölge merkezlerine göre daha etkin olduğunu belirlemiştir. Yakut, Harbalıoğlu ve Pekkan (2015), BIST 100'de işlem gören dokuz adet turizm işletmesinin mali tablolarını kullanarak 2009-2013 yılları arasındaki finansal etkinliklerini VZA ve MTFVE yardımıyla araştırmışlardır. Belirlenen kriterlere göre analiz sonucunda etkin ve etkin olmayan turizm işletmelerini tespit etmişlerdir.

Yi ve Liang (2015), 21 ili ve yedi yılı kapsayan panel veri kullanarak, VZA ve MTFVE yardımıyla turizm etkinliğinin geçici dinamiklerini araştırmak için modeller geliştirmeyi amaçlamışlardır. Sonuçlar öncelikle, bölgenin bir bütün olarak nispeten yüksek turizm etkinliğine sahip olduğunu göstermiştir. Ancak şehirlerarasındaki çeşitlilikler oldukça büyüktür. İkinci olarak, şehirlerarasında farklılıklar olmasına rağmen MTFVE, turizm etkinliğinin artan bir trende sahip olduğunu göstermiştir. Üçüncü sonuç, turizm etkinliğinin büyüklüğüne ve değişimine bağlı olarak, şehirlerin dört kategoride sınıflandırılabildiğini ortaya koymuştur. Dördüncü sonuç, geliştirilen dört turizm etkinliği modelinin; sabit model, alternatif model, yenilikçi model ve radikal model olduğunu göstermiştir. Çelik (2016), Borsa İstanbul turizm sektöründe yer alan konaklama işletmelerinin etkinlik düzeylerini farklı girdi ve çıktılardan oluşan iki ayrı VZA ile ölçmüştür. Ölçeğe göre sabit getiri modelinde her iki analizde iki farklı işletmeyi etkin bulmuş, ayrıca ölçeğe göre değişken getiri modelinde ikisi aynı olmak üzere dörder işletmeyi etkin bulmuştur. İlk analizde etkin çıkan işletmelerden ikinci analizde etkin çıkmayanlar için faaliyetlerindeki başarıyı veya etkinliği gelir veya karlılığa dönüştüremedikleri sonucuna ulaşmıştır. Çakmak ve Örkcü (2016), sağlık, eğitim, ekonomi ve banka alanlarında VZA'ni kullanarak Türkiye'deki 81 ilin sosyoekonomik göstergeler ile etkinliklerini değerlendirmişlerdir. Söz konusu alanlarda etkin olan illeri bulup, etkin olmayan iller için referans değerlerini belirlemişlerdir. Gümüştekin ve Şenel (2017), Tür- 
kiye'deki 81 ilin 2006-2015 yılları arasındaki turizm etkinliklerini MTFVE'yi kullanarak değerlendirmişlerdir. Sadece Balıkesir ve Antalya'nın tüm yıllar boyunca etkin çıktığı, teknik etkinliğin en yüksek olduğu dönemin 2013-2014 yılları olduğu, teknolojik etkinliğin en yüksek olduğu dönemin 2006-2007 yılları olduğu, teknik ve teknolojik etkinliğin birbirine en yakın olduğu dönemin 2009-2010 yılları olduğu bulgusuna ulaşmışlardır. İstanbullu Dinçer ve Göral (2017), VZA ve TOPSIS Temelli Etkinlik Sıralama (ESM-VT) yöntemlerini kullanarak, konaklama kapasitesi kullanımı etkinlik düzeylerine göre illeri sıralamışlardır. Mevcut kriterlerin ağırlıklarının belirlenmesinde Entropi yöntemini ele almışlardır. İlerin konaklama kapasitesi kullanım etkinliğinin sırasıyla Konya, Afyon, Gaziantep, Mersin, Balıkesir, Bursa, Nevşehir, Aydın, Ankara, İzmir, Antalya, Muğla, İstanbul şeklinde olduğu sonucuna varmışlardır. Doğan ve Ersoy (2018), Yozgat'ta faaliyet gösteren 12 konaklama işletmesinin etkinliğini VZA ile ölçmüşlerdir. Analiz sonucunda etkin olan ve olmayan işletmeler belirlenmiş ve etkin olmayanların etkin olabilmesi için öneriler sunulmuştur. Göral (2018), dünyanın önde gelen uluslararası turizm destinasyonlarının (19 ülkenin) turizm sektörü etkinliğini, VZA ve ESM-VT yöntemlerini kullanarak karşılaştırmışlardır. Turizm sektörü etkinliğine göre Hong Kong, $A B D$ ve Hindistan'ın ilk üç sırada, Meksika ve Rusya'nın son sıralarda olduğunu bulmuşlardır. Göral ve Uygur (2018), 19 ülkenin 2013, 2015, 2017 yıllarındaki turizm sektörü etkinliğini ve verimliliğini karşılaştırmak için bir metodoloji oluşturmayı amaçlamışlardır. VZA temelli MTFVE yöntemini kullanarak, turizm sektörüne ilişkin Teknik Etkinlik Değişimini (TED), Teknolojik Etkinlik Değişimini (TKD), Saf Teknik Etkinlik Değişimini (SED), Ölçek Etkinliği Değişimini (ÖED) ve Toplam Faktör Verimliliği Değişimini (TFVD) hesaplamışlardır. Bayrak ve Bahar (2018), 2011-2015 yıllarında OECD ülkelerinin turizm etkinliğinin iktisadi analizini statik ve dinamik VZA'ni kullanarak yapmışlardır. ABD, Avustralya, İspanya, Lüksemburg, Portekiz, Türkiye ve Yeni Zelanda'nın tüm yıllarda etkin ülkeler olduğunu gözlemlemişlerdir. Beş yıllık verilerin topluca değerlendirildiği dinamik analiz sonucunda ise ABD, Avustralya, İspanya, Lüksemburg, Portekiz, Türkiye, Yeni Zelanda ve Yunanistan'ın etkin ülkeler olduğu sonucuna ulaşmışlardır.

\section{Veri Zarflama Analizi}

İşletmelerde performans, etkinlik ve verimliliği ölçme ve değerlendirme üzerine birçok yöntem kullanılmaktadır. En yaygın kullanılanlarından bir tanesi, VZA'dır. VZA, doğrusal programlamaya dayanan, birden fazla ve farklı ölçeklerle ölçülmüş veya farklı ölçü birimlerine sahip girdi ve çıktıların karşılaştırılması durumlarında, çoklu girdiyi çoklu çıktıya dönüştürmekten sorumlu karar verme birimlerinin (okul, banka, lokanta, otel vb.) göreli etkinliğini değerlendirmek için geliştirilmiş parametrik olmayan bir yöntemdir (Benli, 2012; Yakut vd., 2015; Karakaya vd., 2014; Çelik, 2016). VZA'de çoklu girdi ve çıktı kullanıldığı için bu yöntem birçok değişik alanda uygulanabilmektedir.

VZA'da temel ilke, tüm firmaların benzer stratejik amaçlara sahip olmaları ve aynı girdiyi kullanarak, aynı çıktıyı üretebilmeleridir. Bu yöntem sorun tanıma, değerlendirme ve çözme aşamalarında sağladığı faydalardan dolayı çok kullanışı bir etkinlik ölçme aracıdır. Çok sayıda girdi ve çıktı değişkenlerinin olduğu üretim sistemlerinde herhangi bir üretim fonksiyonuna ihtiyaç duymadan ölçüm yapabilmektedir (Yakut vd., 2015).

VZA kapsamında karar birimleri seçiminde, özellikle aynı kararların uygulandığı ve benzer organizasyona sahip olan karar verme birimlerinin seçilmesi önemlidir. Modelde yer alan karar birimleri sayısının girdi ve çıktıların toplamının en az üç katı olması öngörülmektedir. Aynı zamanda araştırmanın güvenilirliği açısından da sıklıkla, karar birimi sayısının girdi ve çıktı sayısının 
toplamından bir fazla veya girdi ve çıktı sayısının çarpımının iki katı kadar olması kuralının uygulandığı görülmektedir (Çelik, 2016). VZA, homojen olan karar birimlerini kendi arasında kıyaslamaktadır. Daha sonra en iyi gözlem etkinlik sınırı olarak belirlenip, diğer gözlemler bu etkin gözleme göre değerlendirilmektedir. Bu etkinlik sınırı ile bir işletmenin en az kaynak kullanımıyla ne kadar çıktı elde edebileceği veya verilen girdilerle elde edebileceği maksimum çıktı miktarı açıklanmaktadır (Uyar ve Alış, 2014). Eğer herhangi bir karar birimi, bu sınır üzerinde ise "etkin", söz konusu sınır üzerinde değilse "etkin olmayan" karar birimi olarak değerlendirilmektedir (Karakaya vd., 2014).

VZA'da iki kısıt bulunmaktadır. İlk kısıt, hiçbir ağırlığın negatif değer taşımaması, ikinci kısıt ise analize konu olan diğer karar birimlerine de uygulandığında hiçbir karar biriminin etkinliğinin 1 'i yani \% 100'ü geçmemesidir. Söz konusu kısıtlar altında yöntem her karar birimine girdi ve çıktılarını istediği gibi ağırlıklandırma imkânı vermektedir (Çelik, 2016; Karakaya vd., 2014). VZA modellerinde, girdi odaklı veya çıktı odaklı olarak iki yaklaşımdan hangisi seçilerek, teknik etkinliğin ölçüleceğine karar vermek gerekmektedir. Girdi odaklı yaklaşımda, belirli bir çıktıyı üretmede kullanılacak en az girdi miktarı (girdi minimizasyonu); çıktı odaklı yaklaşımda ise belirli bir girdiyle en fazla üretilecek çıktı miktarı (çıktı maksimizasyonu) baz alınmaktadır (Benli, 2012). Her bir sistemin girdi ve çıktı ağırlıklarını ve etkinlik derecelerini belirleyen farklı VZA yöntemleri vardır. Hangi yöntemin kullanılacağı, yapılacak araştırmanın niteliğine göre değişmektedir. Bu çalışma kapsamında, VZA metodolojisi ile BCC Modeli - VRS zarflama yüzey tipi ${ }^{7}$ seçilerek, 81 ilden oluşan karar verme birimi etkinlik düzeyleri analiz edilmektedir. Analizde kullanılan model aşağıda sunulmuştur.

$$
\begin{aligned}
& \max Z_{k ;} \\
& Z_{k} Y_{r k}-\sum_{j=1}^{n} \eta_{j k} Y_{r j} \leq 0 \\
& \sum_{j=1}^{n} \eta_{j k} X_{i j} \leq X_{i k} \\
& \sum_{j=1}^{n} \eta_{j k}=1 \\
& \eta_{j k} \geq 0
\end{aligned}
$$

Kisıtlar;

Karar verme birimlerinin ölçeğe göre sabit getiriye sahip oldukları varsayılıyorsa ve birimlerin toplam etkinlik skorları hesaplanmak isteniyorsa, Charnes, Cooper ve Rhodes (1978) tarafın-

\footnotetext{
$7 \mathrm{r}$; üretilen çıktı miktarı $(\mathrm{r}=1,2,3, \ldots . ., \mathrm{s})$

i ; kullanılan girdi miktarı $(\mathrm{i}=1,2,3, \ldots . ., \mathrm{m})$

k ; karar birimi

j ; karar birimi

$\mathrm{n}$; karar birimi sayısı

$\mathrm{Y}_{\mathrm{rk}} ; \mathrm{k}$ karar birimi tarafından üretilen $\mathrm{r}$ çıktı miktarı

$\mathrm{X}_{\mathrm{ij}}$; j karar birimi tarafından kullanılan i girdi miktarı

$\mathrm{Y}_{\mathrm{rj}}$; j karar birimi tarafından üretilen $\mathrm{r}$ çıtı ı miktarı
} 
dan geliştirilen CCR modelleri kullanılabilir. Karar verme birimlerinin ölçeğe göre değişken getiriye sahip oldukları varsayılıyorsa ve yalnızca birimlerin teknik etkinlikleri hesaplanmak isteniyorsa, Banker, Charnes ve Cooper (1984) tarafından geliştirilen BCC modelleri kullanılabilir (Uyar ve Alış, 2014). Teknik olarak etkin olan bir karar verme biriminin ölçekten kaynaklanan bir etkinsizliği varsa, toplam etkinlik skorunu da olumsuz yönde etkiler. Dolayısıyla CCR ve BCC modelleri birlikte ele alınıp, karar verme birimlerinin ölçek etkinlikleri hesaplanabilmektedir (Yakut vd., 2015; Karakaya vd., 2014).

\section{Ampirik Analiz}

\subsection{Veriler ve Kullanılan Değişkenler}

Bu çalışmada amaç, Türkiye'de 2005-2015 yılları arasında VZA kullanılarak sosyal ve ekonomik göstergelere göre Türk turizminde illerin teknik etkinliğini belirlemektir. Analizde kullanılan veriler Maliye Bakanlığı Muhasebat Genel Müdürlüğü, Ekonomi Bakanlığı, Bankalar Birliği ve Turizm Bakanlığı'ndan elde edilmiştir. Sosyal göstergelere göre etkinlik analizi için kullanılan girdi değişkenleri turizm işletme belgesi olan tesis sayısı, oda sayısı, yatak sayısı, turizme yönelik teşvikli belge sayısı ve teşvikli istihdamdır. Ekonomik göstergelere göre etkinlik analizi için kullanılan girdi değişkenleri ise turizme yönelik teşvikli sabit yatırımlar, turizm sektörü için verilen ihtiyaç kredileri, illerde kamu hizmetlerine yapılmış olan harcamalardır (savunma hizmetleri, kamu düzeni ve güvenliği, çevre koruma, dinlenme, kültür hizmetleri gibi). Çıktı değişkenleri olarak ise toplam gelen turist sayısı ve toplam geceleme sayıları alınmıştır (bkz. Şekil 2 ve Şekil 3).

Çalışmada asıl amaç, mevcut girdiler ile maksimum çıktının sağlanması olduğu için çıktı odaklı ve ölçeğe göre değişen getiri (VRS) tipi şeklinde zarflama yüzeyi seçilerek analiz yapılmıştır. Etkinlik değerlerinin elde edilmesinde Frontier Analyst paket programından faydalanılmıştır.

Şekil 2: Sosyal Göstergelere Göre Etkinlik Analizinde Kullanılan Girdi ve Çıktı Değişkenleri

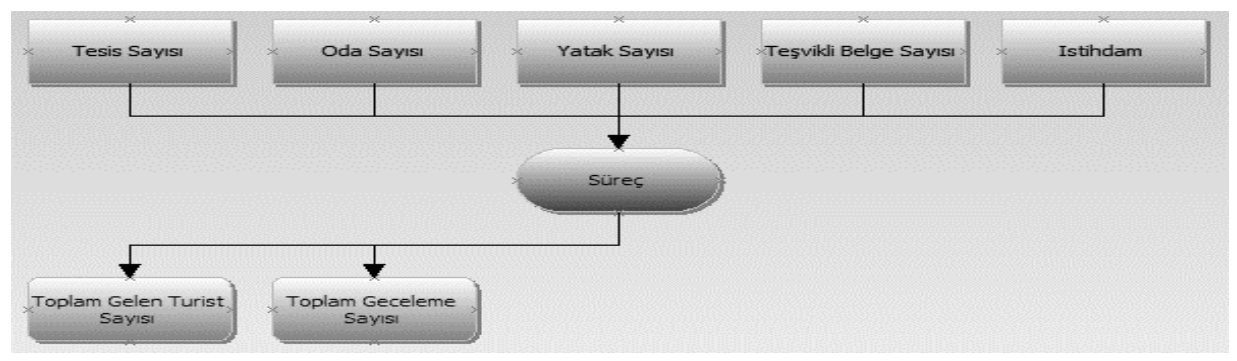

Şekil 3: Ekonomik Göstergelere Göre Etkinlik Analizinde Kullanılan Girdi ve Çıktı Değişkenleri

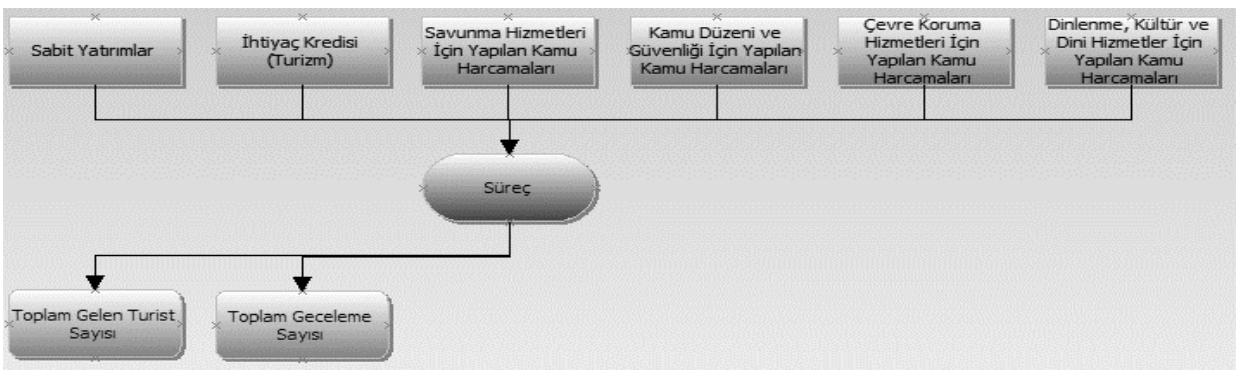




\subsection{Bulgular}

Bu çalışma, kalkınma için sürdürülebilir turizmin önemi ve turizme yönelik kamu teşvik politikaları çerçevesinde sosyal ve ekonomik göstergelere göre illerin turizm açısından etkinlik düzeylerini tespit etmeyi amaçlamaktadır. Ek Tablo 1 ve Ek Tablo 2, Türk turizminde sosyal ve ekonomik göstergelere göre etkinlik analizi sonuçlarını göstermektedir. Ek Tablo 1'de görüldüğü gibi Türk turizminde sosyal değişkenlere göre yapılan etkinlik analizi sonucunda 2005-2015 döneminde tüm yıllarda etkin olan ilin Antalya olduğu görülmektedir. Ekonomik değişkenlere göre yapılan analizde ise Antalya ve Nevşehir'in tüm yıllarda etkin olduğu görülmektedir. 2005-2015 yılları arasında ülkemize gelen turist sayısına bakıldığında 2005 yılının sonlarında ve 2006 yılının ilk çeyreğinde meydana gelen kuş gribi salgını 2006 yılı turizmini önemli derecede etkilemiş olup bir önceki yıla göre \%6 azalmasına sebep olmuştur (Göçen vd., 2011). Ek Tablo 1 ve Ek Tablo 2'den de görüldüğü gibi 2006 yılında illerin etkinliğinde bir azalma söz konusu olmuştur. 20072009 döneminde bütün dünyada baş gösteren küresel ekonomik kriz ve 2009' daki domuz gribi turizmde azalmaya neden olmasa da artış hızını azaltmıştır. 2007'de \%18'e yükselen turist sayısı, 2008 de \%13 ve 2009 ise sadece \%3'e yükselmiştir. Ayrıca tüm yıllarda turistlerin turistik amaçlı otel sayılarına bakıldığında 2006 yılındaki kuş gribinde otel sayısı \%3 azalırken, 5 yıldızlı otel sayısı ise bir önceki yıla göre \%10 artmıştır. Genel olarak ülkemizdeki ekonomik krizlerin ve salgınların toplam otel sayılarını ve 5 yıldızlı otel sayılarını olumsuz etkilemediği söylenebilir. Turizm gelirlerine bakıldığında 2005 yılı turizm gelirleri bir önceki yıla göre \% 14,26 oranında artarak 18 153,5 milyon \$ olarak gerçekleşmiştir. 2006 yılı turizm gelirleri bir önceki yıla göre \% 7,18 oranında azalarak 16 850,8 milyon \$ olarak gerçekleşmiştir. Dünyada küresel krizin yaşandığı 2008 yılında ise turizm geliri, 2007 yılına oranla \%18,5 artarak, 21910 milyon \$’a yükselmiştir. Aynı şekilde krizin etkisini göstermeye devam ettiği 2009 yılında ise turizm geliri 2008 yılına göre yaklaşık \%3 azalarak 21249 Milyon \$’a gerilemiştir. Bu göstergeler bu çalışmadan elde edilen bulgularla paralellik göstermektedir (Göçen vd., 2011).

Bu çalışmada Ek Tablo 1 incelendiğinde, sosyal değişkenlere göre tüm yıllarda etkin olan il yüzdesine bakıldığında 2008 krizi sonrası etkin olan illerin oranının azaldığı görülmektedir. 2008 krizi sonrası etkin olan illerin oranı \%7,4'e düşerken bu tarihten sonra tekrar yükseliş göstermiştir. Ek Tablo 2'deki ekonomik değişkenlere göre etkin olan illerin oranına bakıldığında yine 2008 krizi sonrası bir düşüş yaşanmış ve sonrasında etkin olan illerin oranında bir artış gözlenmiştir. Ekonomik değişkenlere göre etkinlik oranının en fazla olduğu yıl 2008'dir. Sosyal değişkenlere göre yapılan analiz sonucunda ise etkinlik oranının en fazla olduğu yıl 2015'dir. Bu yılda en düşük etkinliğe sahip olan il Bayburt'tur.

Türkiye İstatistik Kurumu (TÜiK), Suriye vatandaşlarının ülkeye geliş gidişlerine ilişkin turizm istatistiklerinde yapılan revizyon sonucunda, 2013 yılının ilk yarısında turizm gelirinde 630 milyon dolar düşüşün meydana geldiğini açıklamıştır. Suriye'de başlayan ve 2012 yılı başından itibaren yoğunluk kazanan iç savaşın, bu ülkeden gelenlerin sayılarında dikkate değer nitelikte artışa neden olduğu belirtilmiştir. 2012 yılı 3. döneminde 119,6 milyon dolar ve 4. döneminde ise 224,8 milyon dolar olmak üzere 2012 yılında toplam turizm gelirinde 344,4 milyon dolar bir düşüş olmuştur. 2013 yılında ise 1 . dönemde 268,7 milyon dolar ve 2. döneminde ise 361,3 milyon dolar olmak üzere 2013 yılının ilk iki döneminde turizm gelirinde 630 milyon dolar düşüş meydana gelmiştir. Ek Tablo 1 ve Ek Tablo 2 incelendiğinde 2013 yılında hem sosyal hem de ekonomik göstergelere göre etkin olan illerin oranında bir azalış meydana geldiği görülmektedir. 


\section{Sonuç}

Bu çalışma, kalkınma için sürdürülebilir turizmin önemi ve turizme yönelik kamu teşvik politikaları çerçevesinde sosyal ve ekonomik göstergelere göre illerin turizm açısından etkinlik düzeylerini tespit etmeyi amaçlamaktadır. Türk turizminde sosyal değişkenlere göre yapılan etkinlik analizi sonucunda 2005-2015 döneminde tüm yıllarda etkin olan ilin Antalya olduğu görülmektedir. Bu sonuç Gümüştekin ve Şenel (2017)'in çalışmasını desteklemektedir. Ekonomik değişkenlere göre ise yapılan analizde Antalya ve Nevşehir'in tüm yıllarda etkin olduğu görülmektedir. Bu bulgu Çakmak ve Örkcü (2016)'nün elde ettiği sonuçlarla uyumlu değildir. Çakmak ve Örkcü (2016) ekonomi alanı için analizlerinde İstanbul, Kocaeli, Bayburt, Şırnak ve Ardahan illerinin etkin iller konumunda olduğunu tespit etmişlerdir. Bu çalışmada sosyal değişkenlere göre tüm yıllarda etkin olan il yüzdesine bakıldığında 2008 krizi sonrası etkin olan illerin oranının azaldığı görülmektedir. 2008 krizi sonrası etkin olan illerin oranı \%7,4'e düşerken bu tarihten sonra tekrar yükseliş göstermiştir. Ekonomik değişkenlere göre etkin olan illerin oranına bakıldığında yine 2008 krizi sonrası bir düşüş yaşanmış ve sonrasında etkin olan illerin oranında bir artış gözlenmiştir. Ekonomik değişkenlere göre etkinlik oranının en fazla olduğu yıl 2008 'dir. Sosyal değişkenlere göre yapılan analiz sonucunda ise etkinlik oranının en fazla olduğu yıl ise $2015^{\prime}$ dir.

Günümüzde hemen hemen her ülke kriz ve afetlerden etkilenmektedir. Dünyanın bir yerinde yaşanan kriz çok geniş alanda etkili olabilmektedir. Türkiye'de kuş gribinin meydana geldiği 2006 yılında ve domuz gribinin yayıldığı 2009 yılında turizm sektörü oldukça gerilemiştir. Suriye vatandaşlarının Türkiye'ye gelmesinin etkisiyle 2013 yılında ise turizm gelirleri azalmış ve Türk turizminde etkin olan illerin oranında bir azalış meydana gelmiştir. Ekonomik krizlerin görüldüğü yıllarda ise turizm sektörü yine de büyüyebilmiştir. Çünkü bu durumdan daha çok yurt içindeki vatandaşlar etkilenmiştir. Ancak küresel krizin yaşandığı 2008 yılında bütün dünya etkilenmiş ve Türkiye turizm gelirinde yüksek bir artış sağlayamamıştır.

Bir taraftan kalkınma için sürdürülebilir turizm söylemleri yapılırken, diğer taraftan dünya genelinde sera gazı emisyonunun \%5'ini turizm sektörünün oluşturduğu düşünüldüğünde, gerekli tedbirlerin alınması kaçınılmazdır. Nitekim, tedbir alınmadığı ve olağan seyrine bırakılması halinde 2035 yılında sera gazı emisyon oranının \%130 artacağı tahmin edilmektedir. Küresel kamusal bir sorun olarak karşımıza çıkan bu durumda, kalkınma için sürdürülebilir turizmin geliştirilmesi konusunda devletin öncü ve düzenleyici rol oynaması kaçınılmaz hal almıştır. Nitekim sektörün bölünmüş yapısı yasal düzenlemelerle koordinasyon ihtiyacı gerektirirken; kültürel mirasın sürdürülebilirliği teşvik uygulamalarını, sürdürülebilirlik çalışmalarının maliyetli süreci ise özellikle gelişmekte olan ülkelerde devlet desteği ve sübvansiyonları gerekli kılmaktadır (TÜSiAD, 2012).

Kalkınma için sürdürülebilir turizm çerçevesinde küresel düşünerek bir takım adımların atılması gerekmektedir. Sürdürebilir turizmin gereği, çalışanların yönetime ve sisteme aktif olarak katılımları sağlanmalıdır. Çalışanların turizme yönelik performansı arttırıcı fikirleri de bu bağlamda yol gösterici olabilmektedir. 


\section{Kaynaklar}

Anumat, Prad; Saosaowapak, Anuphak (2013), “Determinants of International Tourism Receipts and Technical Efficiency of Tourism Sector in Malaysia, Thailand and Singapore", The Empirical Econometrics and Quantitative Economics Letters, Vol. 2, No. 3: 111-116.

Babacan, Adem; Özcan, Selami (2009), “Alanya Bölgesi Otellerinin Göreli Etkinliğinin Belirlenmesi: Bir Veri Zarflama Analizi Tekniği Uygulaması”, Mustafa Kemal Üniversitesi Sosyal Bilimler Enstitüsü Dergisi, C. 12, S. 6: 176-189.

Bahar, Ozan; Kozak Metin (2013), Turizm Ekonomisi. Eskişehir: Anadolu Üniversitesi AÖF Yayını.

Bayrak, Rıza; Bahar, Ozan (2018), "Economic Efficiency Analysis of Tourism Sector in OECD Countries: An Emprical Study with DEA", Uiiid-International Journal of Economic and Administrative Studies, Vol. 20: 83-100.

Benli, Yasemin Keskin (2012), "Veri Zarflama Analizi (VZA) ve Malmquist Toplam Faktör Verimliliği (TFV): Konaklama İşletmelerinde Bir Uygulama”, Ege Akademik Bakış, C. 12, S. 3: 369-382.

$\mathrm{Bi}$, GongBing, Luo, Yan; Liang, Liang (2011), "Efficiency Evaluation of Tourism Industry With Data Envelopment Analysis (DEA): A Case Study in China”, Journal of China Tourism Research, Vol.7: 104-116.

Chien, Feng-sheng Julian (2014), "A Study on the Operating Efficiency of Taiwan Tourist Hotels", The SIJ Transactions on Industrial, Financial \& Business Management (IFBM), Vol. 2, No. 3: 62-71.

Civelek, Ayşen (2010),"Turizmin Sosyal Yapıya ve Sosyal Değişmeye Etkileri", Selçuk Üniversitesi Sosyal Bilimler Meslek Yüksekokulu Dergisi, C.13, S. 1/2: 331-350.

Çakmak, Eda; Örkcü, H. Hasan (2016), "Türkiye'deki illerin Etkinliklerinin Sosyo-Ekonomik Temel Göstergelerle Veri Zarflama Analizi Kullanarak İncelenmesi”, Karabük Üniversitesi Sosyal Bilimler Enstitüsü Dergisi, C. 6, S. 1: 30-48.

Çelik, Melike Kurtaran (2016), "Turizm Sektöründeki İşletmelerinin Etkinliklerinin Veri Zarflama Analizi İle Ölçülmesi”, Uluslararası Iktisadi ve Idari Incelemeler Dergisi, C. 17: 65-88.

Doğan, Nuri Ö.; Ersoy, Yusuf (2018), "Veri Zarflama Analizi ile Konaklama İşletmelerinde Etkinlik Ölçümü: Yozgat ili Örneği", Mukaddime, C. 9, S. 2: 119-134.

Emir, Oktay; Özgür, Ersan (2008), “Konaklama Tesisleri Etkinlik Analizi”, Afyon Kocatepe Üniversitesi Sosyal Bilimler Dergisi, C. 10, S. 1: 163-175.

Erciş, M. Serdar; Gülcü, Aslan (2008), “Veri Zarflama Analizi Yöntemiyle Konaklama İşletmelerinin Etkinliklerinin Ölçümü ve Bir Uygulama”, Trakya Üniversitesi 17. İstatistik Araştırma Sempozyumu Bildiriler Kitabı.

Göçen, Sedat; Yirik, Şevket; Yılmaz, Yusuf (2011), "Türkiye'de Krizler ve Krizlerin Turizm Sektörüne Etkileri”, Süleyman Demirel Üniversitesi Iktisadi ve Idari Bilimler Fakültesi Dergisi, C. 16, S. 2: 493-509.

Göral, Ramazan (2018), “ESM-VT Yöntemi ile Uluslararası Destinasyonların Turizm Sektörü Etkinliğinin Değerlendirilmesi", Journal of Tourism and Gastronomy Studies, C. 6, S. 2: 436-455.

Göral, Ramazan; Uygur, Akyay (2018), "Malmquist-TFV Endeksi ile Uluslararası Turizm Destinasyonlarının Verimliliklerinin Karşılaştırılması", Journal of Tourism Theory and Research, Vol. 4, No. 2: 70-86.

Gül, Hasan (2013), "Turizm Sektöründe Yeni Eğilimler, Uygulamalar ve Bunların Sektöre Etkisi: Turizm Sektöründe Vergi Indirimi ve Ekonomik Etkileri", Mehmet Kemal Dedeman Araştırma ve Geliştirme Proje Yarışması 2013. Turizm Sektörü İkincilik Ödülü. Antalya.

Gümüştekin, Serpil; Şenel, Talat (2017), "Türkiye'nin Turizm Performansının Değerlendirilmesi”, XVIII. Uluslararası Ekonometri Yöneylem Araştırması ve Istatistik Sempozyumu Bildiriler Kitabı.

İstanbullu Dinçer, Füsun; Göral, Ramazan (2017), “VZA Temelli TOPSiS Metodu ile Konaklama Kapasitesinin Etkin Kullanımı Açısından İllerin Sıralanması", Anemon Muş Alparslan Üniversitesi Sosyal Bilimler Dergisi, C. 5, S. 2: 539-558.

Karakaya, Aykut; Kurtaran, Ahmet; Dağlı, Hüseyin (2014), "Bireysel Emeklilik Şirketlerinin Veri Zarflama Analizi Ile Etkinlik Ölçümü: Türkiye Örneği”, Yönetim ve Ekonomi Araştırmaları Dergisi, C. 22: 1-23.

Oliveria, Ricardo; Pedro, Maria Isabel; Marques, Rui Cunha (2013), "Efficiency and Its Determinants in Portuguese Hotels in the Algarve", Tourism Management, Vol. 36: 641- 649.

Önen, M. Oğuzhan (2000), “Türkiye'nin Turizm Sektöründeki Gelişmeler, Dünya Turizmindeki Yeri ve Türkiye Kalkınma Bankası'nın Rolü”, Türkiye Kalkınma Bankası A.Ş. Sektörel Araştırmalar, Ankara: SA/00-2-5.

Sarsın Kaya, Dilek (2017), "Turizm Sektörü",Türkiye İ̧̧ Bankası Iktisadi Araştırmalar Bölümü, Mart 2017.

Shieh, Hwai-Shuh; Hu, Jin-Li; Gao,Li-Ying (2014), "Tourist Preferences and Cost Efficiency of International Tourist Hotels in Taiwan", International Journal of Marketing Studies, Vol. 6, No. 3: 35-48. 


\section{Eskişehir Osmangazi Üniversitesi Iïß Dergisi}

T.C. Kalkınma Bakanlığı (2014), Onuncu Kalkınma Planı 2014-2018 - Turizm Özel Ihtisas Komisyon Raporu 2023,No. KB: 2859 - Öік: 713,Ankara.

T.C. Kültür ve Turizm Bakanlığı (2017), “Turizm Sektörü Acil Eylem Planı Destekleri ve Turizm Sektörüne Yönelik İstidam Destekleri",

http://yigm.kulturturizm.gov.tr/Eklenti/50733, turizmsektoruacileylemplanidestekleriveturizmsektoruney-.pdf?0(Erişim: 18.07.2017)

T.C. Kültür ve Turizm Bakanlığı (2017). "Turizm İşletme Belgeli Tesislere Sağlanan Diğer Avantajlar",

http://yigm.kulturturizm.gov.tr/Eklenti/55966,turizm-isletme-belgeli-tesislere-saglanan-diger-avantaj-.pdf?0

(Erişim: 22.12.2017).

Toker, Boran (2007), “Türkiye'de Turizm Sektörü Teşviklerinin Değerlendirilmesi”,Yönetim ve Ekonomi, C. 14. S. 2.

TÜSİAD (2012), Sürdürülebilir Turizm. No. TÜSİAD-T/2012-09/531. İstanbul.

Toma, Elena (2014), "Regional Scale Efficiency Evaluation by Input-oriented Data Envelopment Analysis of Tourism Sector", International Journal of Academic Research in Environment and Geography, Vol. 1, No. 1: 15-20.

United Nations Environment Programme (UNEP); UNWTO (2005), Making Tourism More Sustainable a Guide for Policy Makers. UNEP - ISBN: 92-807-2507-6. UNWTO - ISBN: 92-844-0821-0. France-Spain.

UNWTO (2015), United Nations Declares 2017 as the International Year of Sustainable Tourism for Development. 07.Dec.15. PR No. 15094.

Uyar, Süleyman; Alış, Mehmet (2014), “Konaklama İşletmelerinde Veri Zarflama Analizi Yöntemiyle Faaliyet Denetimi Uygulaması”, Dokuz Eylül Üniversitesi Iktisadi ve Idari Bilimler Fakültesi Dergisi, C. 29, S. 2: 107-136.

World Travel and Tourism Council (2017), Travel \& Tourism Economic Impact 2017 Turkey. March 2017.

Yakut, Emre; Harbalıoğlu, Melda; Pekkan, Nazmiye Ülkü (2015), “Turizm Sektöründe BIST’a Kayıtlı İşletmelerin Veri Zarflama Analizi ve Toplam Faktör Verimliliği ile Finansal Performanslarının İncelenmesi”, İşletme Araştırmaları Dergisi, C. 7, S. 2: 235-257.

Yi, Tingting; Liang, Mingzhu (2015), "Evolutional Model of Tourism Efficiency Based on the DEA Method: A Case Study of Cities in Guangdong Province, China", Asia Pacific Journal of Tourism Research, Vol. 20, No. 7: 789-806

Zengin, Burhanettin; Çömlekçi, İstemi; Mesci, Zeynep (2013), "Finansal Performansa Dayalı Etkinlik Ölçümü: Turizm İşletmelerine Yönelik Bir Araştırma", Finans Politik ve Ekonomik Yorumlar Dergisi, C. 50, S. 57 
Ekler:

Tablo 1. Türk Turizminde Sosyal Değişkenlere Göre Etkinlik Skorları

\begin{tabular}{|c|c|c|c|c|c|c|c|c|c|c|c|c|}
\hline \multirow{2}{*}{ ILLER } & \multicolumn{11}{|c|}{ YILLAR } & \multirow{2}{*}{$\begin{array}{c}\text { Orta- } \\
\text { lama } \\
\text { etkinli }\end{array}$} \\
\hline & 2005 & 2006 & 2007 & 2008 & 2009 & 2010 & 2011 & 2012 & 2013 & 2014 & 2015 & \\
\hline ADANA & 0.75 & 0.81 & 0.21 & 0.73 & 0.67 & 0.71 & 0.63 & 0.62 & 0.76 & 0.96 & 1.00 & 0.71 \\
\hline ADIYAMAN & 0.90 & 0.63 & 0.43 & 1.00 & 0.57 & 0.67 & 0.43 & 0.45 & 0.47 & 0.93 & 0.92 & 0.67 \\
\hline $\begin{array}{l}\text { AFYONKARAHI- } \\
\text { SAR }\end{array}$ & 0.72 & 1.00 & 0.15 & 0.63 & 0.70 & 0.71 & 0.83 & 0.66 & 1.00 & 1.00 & 1.00 & 0.76 \\
\hline AĞRI & 0.65 & 0.22 & 0.57 & 0.68 & 0.14 & 0.06 & 0.18 & 0.19 & 0.26 & 0.84 & 0.81 & 0.42 \\
\hline AKSARAY & 0.62 & 0.42 & 0.78 & 0.80 & 0.54 & 0.65 & 0.70 & 0.47 & 0.48 & 0.98 & 0.96 & 0.67 \\
\hline AMASYA & 0.65 & 1.00 & 0.49 & 0.69 & 0.44 & 0.40 & 0.55 & 0.57 & 0.48 & 0.96 & 0.96 & 0.65 \\
\hline ANKARA & 1.00 & 1.00 & 1.00 & 1.00 & 0.89 & 1.00 & 0.99 & 1.00 & 1.00 & 1.00 & 0.98 & 0.99 \\
\hline ANTALYA & 1.00 & 1.00 & 1.00 & 1.00 & 1.00 & 1.00 & 1.00 & 1.00 & 1.00 & 1.00 & 1.00 & 1.00 \\
\hline ARDAHAN & 0.40 & 0.48 & 0.48 & 1.00 & 0.32 & 0.68 & 0.72 & 1.00 & 0.71 & 0.93 & 1.00 & 0.70 \\
\hline ARTVIN & 0.86 & 0.83 & 1.00 & 0.84 & 0.66 & 0.64 & 0.62 & 0.64 & 0.48 & 0.94 & 0.98 & 0.77 \\
\hline AYDIN & 0.90 & 0.72 & 0.03 & 1.00 & 0.80 & 0.70 & 0.77 & 0.89 & 1.00 & 1.00 & 0.99 & 0.80 \\
\hline BALIKESIR & 1.00 & 0.72 & 0.43 & 1.00 & 0.68 & 0.53 & 0.63 & 0.92 & 0.62 & 0.96 & 0.96 & 0.77 \\
\hline BARTIN & 0.55 & 0.34 & 0.03 & 1.00 & 0.34 & 0.41 & 0.42 & 0.37 & 0.31 & 0.89 & 0.90 & 0.51 \\
\hline BATMAN & 0.71 & 0.64 & 0.74 & 0.72 & 0.50 & 0.55 & 0.87 & 0.39 & 1.00 & 1.00 & 0.97 & 0.74 \\
\hline BAYBURT & 0.64 & 0.32 & 1.00 & 0.72 & 0.50 & 0.55 & 0.87 & 0.39 & 1.00 & 1.00 & 0.88 & 0.72 \\
\hline BILECIK & 0.56 & 0.37 & 0.26 & 0.62 & 0.40 & 0.47 & 0.60 & 0.68 & 0.54 & 0.95 & 0.96 & 0.58 \\
\hline BINGÖL & 0.69 & 0.28 & 1.00 & 0.69 & 0.86 & 0.80 & 0.57 & 0.49 & 0.74 & 1.00 & 0.93 & 0.73 \\
\hline BitLis & 0.79 & 0.36 & 1.00 & 1.00 & 0.26 & 0.51 & 0.34 & 0.61 & 0.36 & 0.90 & 0.91 & 0.64 \\
\hline BOLU & 1.00 & 1.00 & 0.85 & 0.63 & 0.69 & 0.63 & 0.61 & 0.71 & 0.70 & 0.95 & 0.98 & 0.80 \\
\hline BURDUR & 1.00 & 1.00 & 0.85 & 1.00 & 0.32 & 0.58 & 0.75 & 0.69 & 0.43 & 0.95 & 0.97 & 0.78 \\
\hline BURSA & 0.74 & 1.00 & 0.19 & 0.98 & 0.66 & 0.71 & 0.67 & 0.69 & 0.77 & 0.97 & 0.98 & 0.76 \\
\hline ÇANAKKALE & 0.60 & 0.65 & 0.55 & 1.00 & 0.67 & 0.59 & 0.63 & 0.71 & 0.78 & 0.98 & 0.98 & 0.74 \\
\hline ÇANKIRI & 0.60 & 0.45 & 0.25 & 0.88 & 0.69 & 0.89 & 0.81 & 0.70 & 0.68 & 0.95 & 1.00 & 0.72 \\
\hline ÇORUM & 0.59 & 0.63 & 0.05 & 0.79 & 0.46 & 0.78 & 0.54 & 0.90 & 0.47 & 1.00 & 0.98 & 0.65 \\
\hline DENIZLi & 1.00 & 1.00 & 0.26 & 1.00 & 1.00 & 1.00 & 1.00 & 1.00 & 1.00 & 1.00 & 1.00 & 0.93 \\
\hline DIYARBAKIR & 1.00 & 0.63 & 1.00 & 0.87 & 0.82 & 1.00 & 0.81 & 0.72 & 0.87 & 0.96 & 0.96 & 0.88 \\
\hline DÜZCE & 0.51 & 0.47 & 0.44 & 0.67 & 0.52 & 0.60 & 0.57 & 0.52 & 0.62 & 0.95 & 0.98 & 0.62 \\
\hline EDIRNE & 0.97 & 0.82 & 0.86 & 0.77 & 0.46 & 0.57 & 0.55 & 0.50 & 0.43 & 1.00 & 0.96 & 0.72 \\
\hline ELAZIĞ & 0.61 & 0.68 & 0.53 & 0.73 & 0.70 & 0.60 & 0.73 & 0.67 & 0.59 & 0.94 & 0.94 & 0.70 \\
\hline ERZINCAN & 0.54 & 0.49 & 1.00 & 1.00 & 0.42 & 0.72 & 0.46 & 0.47 & 0.38 & 0.95 & 0.93 & 0.67 \\
\hline ERZURUM & 0.65 & 1.00 & 0.75 & 0.79 & 0.65 & 0.77 & 1.00 & 1.00 & 0.71 & 0.97 & 0.97 & 0.84 \\
\hline ESKIŞEHIR & 0.92 & 0.70 & 0.51 & 0.90 & 0.75 & 0.75 & 1.00 & 0.73 & 0.71 & 0.96 & 1.00 & 0.81 \\
\hline GAZIANTEP & 0.71 & 0.72 & 0.52 & 0.81 & 0.65 & 0.54 & 0.55 & 0.76 & 0.81 & 0.96 & 0.96 & 0.73 \\
\hline GIRESUN & 0.69 & 0.59 & 0.14 & 0.62 & 0.53 & 0.44 & 0.58 & 0.66 & 0.57 & 0.93 & 0.96 & 0.61 \\
\hline GÜMÜŞHANE & 0.40 & 0.23 & 0.90 & 0.93 & 0.91 & 0.07 & 0.76 & 0.84 & 0.68 & 0.93 & 0.97 & 0.69 \\
\hline HAKKARI & 0.97 & 0.95 & 0.49 & 0.79 & 1.00 & 0.40 & 1.00 & 1.00 & 0.65 & 0.90 & 1.00 & 0.83 \\
\hline HATAY & 0.54 & 0.77 & 1.00 & 0.85 & 0.63 & 0.87 & 0.66 & 0.59 & 0.62 & 0.95 & 0.97 & 0.77 \\
\hline IĞDIR & 0.60 & 0.65 & 0.06 & 0.76 & 0.63 & 0.82 & 0.71 & 1.00 & 0.96 & 1.00 & 1.00 & 0.74 \\
\hline ISPARTA & 0.58 & 0.92 & 0.99 & 0.97 & 0.67 & 0.68 & 0.75 & 0.88 & 0.59 & 0.99 & 0.99 & 0.82 \\
\hline IÇEL-MERSIN & 0.70 & 0.65 & 0.43 & 0.64 & 0.57 & 0.52 & 0.48 & 0.48 & 0.55 & 0.94 & 0.95 & 0.63 \\
\hline ISTANBUL & 1.00 & 1.00 & 1.00 & 0.98 & 1.00 & 1.00 & 1.00 & 1.00 & 1.00 & 1.00 & 1.00 & 1.00 \\
\hline IZMiR & 0.66 & 0.64 & 1.00 & 0.71 & 1.00 & 0.77 & 0.84 & 0.77 & 0.83 & 0.98 & 0.98 & 0.83 \\
\hline
\end{tabular}


Eskişehir Osmangazi Üniversitesi IïBF Dergisi

\begin{tabular}{|c|c|c|c|c|c|c|c|c|c|c|c|c|}
\hline \multirow{2}{*}{ ILLER } & \multicolumn{11}{|c|}{ YILLAR } & \multirow{2}{*}{$\begin{array}{c}\text { Orta- } \\
\text { lama } \\
\text { etkinlik }\end{array}$} \\
\hline & 2005 & 2006 & 2007 & 2008 & 2009 & 2010 & 2011 & 2012 & 2013 & 2014 & 2015 & \\
\hline $\begin{array}{l}\text { KAHRAMANMA- } \\
\text { RAŞ }\end{array}$ & 0.61 & 0.60 & 0.60 & 1.00 & 0.45 & 0.53 & 0.51 & 0.56 & 0.62 & 0.93 & 0.96 & 0.67 \\
\hline KARABÜK & 0.96 & 0.82 & 1.00 & 0.75 & 0.60 & 0.76 & 0.83 & 0.77 & 0.74 & 0.98 & 1.00 & 0.84 \\
\hline KARAMAN & 0.44 & 0.47 & 0.58 & 0.71 & 0.64 & 0.50 & 0.63 & 0.54 & 0.60 & 0.94 & 0.96 & 0.64 \\
\hline KARS & 0.48 & 0.37 & 0.83 & 1.00 & 0.41 & 0.46 & 0.40 & 0.52 & 0.43 & 0.89 & 0.91 & 0.61 \\
\hline KASTAMONU & 0.69 & 0.83 & 1.00 & 0.58 & 0.83 & 0.66 & 0.48 & 0.66 & 0.69 & 0.98 & 0.96 & 0.76 \\
\hline KAYSERi & 0.69 & 1.00 & 0.29 & 0.71 & 0.61 & 0.50 & 0.58 & 0.75 & 0.59 & 0.97 & 1.00 & 0.70 \\
\hline KIRIKKALE & 0.32 & 0.09 & 0.38 & 0.75 & 0.55 & 0.17 & 0.03 & 0.33 & 0.17 & 1.00 & 1.00 & 0.43 \\
\hline KIRKLARELI & 0.50 & 0.38 & 0.71 & 0.53 & 0.51 & 0.87 & 0.26 & 0.36 & 0.33 & 0.93 & 0.95 & 0.58 \\
\hline KIRŞEHIR & 0.60 & 1.00 & 0.11 & 0.74 & 0.81 & 0.27 & 0.44 & 0.43 & 0.60 & 0.99 & 1.00 & 0.64 \\
\hline KiLis & 0.60 & 0.11 & 0.51 & 0.72 & 0.57 & 0.58 & 0.80 & 1.00 & 0.60 & 1.00 & 1.00 & 0.68 \\
\hline KOCAELI & 0.68 & 0.82 & 0.48 & 0.53 & 0.64 & 0.73 & 0.75 & 0.68 & 0.74 & 0.94 & 1.00 & 0.73 \\
\hline KONYA & 0.83 & 0.97 & 0.31 & 0.97 & 0.85 & 0.89 & 0.77 & 1.00 & 0.86 & 0.98 & 0.98 & 0.86 \\
\hline KÜTAHYA & 0.62 & 0.48 & 0.56 & 0.80 & 0.66 & 0.73 & 0.86 & 0.60 & 0.61 & 0.95 & 0.99 & 0.71 \\
\hline MALATYA & 1.00 & 0.80 & 0.52 & 0.72 & 0.47 & 0.61 & 0.58 & 0.62 & 0.53 & 0.94 & 0.96 & 0.70 \\
\hline MANISA & 0.61 & 0.67 & 0.42 & 0.81 & 0.49 & 0.72 & 0.73 & 1.00 & 0.86 & 0.96 & 1.00 & 0.75 \\
\hline MARDIN & 0.32 & 0.60 & 0.68 & 0.78 & 0.55 & 0.82 & 0.47 & 0.48 & 0.57 & 0.96 & 0.92 & 0.65 \\
\hline MUĞLA & 1.00 & 0.71 & 0.04 & 0.33 & 0.76 & 0.70 & 0.70 & 0.68 & 0.77 & 0.98 & 1.00 & 0.70 \\
\hline MUŞ & 0.79 & 0.65 & 0.50 & 0.96 & 0.96 & 1.00 & 0.63 & 0.93 & 0.64 & 0.97 & 0.99 & 0.82 \\
\hline NEVŞEHIR & 0.68 & 0.63 & 1.00 & 0.86 & 0.90 & 0.97 & 1.00 & 1.00 & 0.97 & 1.00 & 0.99 & 0.91 \\
\hline NiĞDE & 1.00 & 0.60 & 0.13 & 0.67 & 0.54 & 0.57 & 0.57 & 0.75 & 0.65 & 0.93 & 0.96 & 0.67 \\
\hline ORDU & 0.67 & 0.86 & 0.97 & 0.89 & 0.53 & 0.43 & 0.51 & 0.62 & 0.61 & 0.96 & 1.00 & 0.73 \\
\hline OSMANIYE & 1.00 & 0.34 & 0.97 & 1.00 & 1.00 & 1.00 & 0.56 & 0.63 & 0.53 & 0.98 & 1.00 & 0.82 \\
\hline RizE & 0.79 & 0.52 & 0.97 & 0.85 & 0.58 & 0.21 & 0.46 & 0.58 & 0.48 & 0.96 & 0.95 & 0.67 \\
\hline SAKARYA & 0.60 & 0.72 & 0.90 & 1.00 & 0.56 & 0.08 & 0.57 & 0.71 & 0.62 & 0.96 & 1.00 & 0.70 \\
\hline SAMSUN & 0.47 & 0.58 & 0.20 & 0.86 & 0.50 & 0.73 & 0.72 & 0.67 & 0.58 & 0.96 & 0.95 & 0.66 \\
\hline SiiRT & 0.47 & 0.58 & 0.20 & 0.86 & 0.50 & 0.73 & 0.72 & 0.67 & 0.58 & 1.00 & 0.89 & 0.66 \\
\hline SINOP & 0.44 & 0.10 & 0.59 & 1.00 & 0.43 & 0.91 & 0.62 & 0.57 & 0.43 & 0.94 & 0.99 & 0.64 \\
\hline SIVAS & 1.00 & 0.55 & 0.60 & 0.74 & 0.96 & 0.98 & 1.00 & 0.92 & 0.82 & 0.97 & 1.00 & 0.87 \\
\hline ŞIRNAK & 1.00 & 1.00 & 1.00 & 0.95 & 0.16 & 0.22 & 0.77 & 0.35 & 1.00 & 1.00 & 1.00 & 0.77 \\
\hline TEKIRDAĞ & 0.69 & 0.53 & 0.77 & 0.54 & 0.48 & 0.44 & 0.35 & 0.49 & 0.47 & 1.00 & 0.99 & 0.61 \\
\hline TOKAT & 0.52 & 0.87 & 1.00 & 0.92 & 0.64 & 0.82 & 1.00 & 0.83 & 0.54 & 0.94 & 0.97 & 0.82 \\
\hline TRABZON & 0.51 & 0.64 & 0.42 & 0.79 & 0.56 & 0.55 & 0.69 & 0.81 & 0.69 & 0.96 & 1.00 & 0.69 \\
\hline TUNCELI & 1.00 & 0.24 & 0.03 & 1.00 & 0.41 & 0.77 & 0.52 & 0.55 & 0.52 & 0.93 & 0.98 & 0.63 \\
\hline URFA & 0.50 & 0.30 & 0.86 & 0.84 & 0.49 & 0.58 & 0.48 & 0.66 & 0.81 & 0.97 & 1.00 & 0.68 \\
\hline UŞAK & 1.00 & 0.81 & 0.53 & 0.84 & 0.74 & 0.72 & 0.98 & 0.57 & 0.58 & 0.95 & 0.96 & 0.79 \\
\hline VAN & 0.58 & 0.91 & 0.64 & 0.83 & 0.84 & 0.82 & 0.74 & 0.52 & 0.45 & 1.00 & 0.97 & 0.75 \\
\hline YALOVA & 0.73 & 0.96 & 0.77 & 0.63 & 0.78 & 0.69 & 1.00 & 0.65 & 0.81 & 0.98 & 1.00 & 0.82 \\
\hline YOZGAT & 0.82 & 0.77 & 0.67 & 1.00 & 0.51 & 0.52 & 0.73 & 0.40 & 0.46 & 0.99 & 1.00 & 0.72 \\
\hline ZONGULDAK & 0.88 & 0.52 & 0.47 & 0.65 & 0.49 & 0.54 & 0.36 & 0.40 & 0.47 & 0.94 & 0.94 & 0.61 \\
\hline $\begin{array}{l}\text { Etkin olan il yüz- } \\
\text { desi }\end{array}$ & 0.20 & 0.16 & 0.19 & 0.22 & 0.07 & 0.09 & 0.10 & 0.15 & 0.11 & 0.21 & 0.30 & \\
\hline $\begin{array}{l}\text { Ortalama Etkin- } \\
\text { lik }\end{array}$ & 0.72 & 0.66 & 0.60 & 0.82 & 0.63 & 0.64 & 0.67 & 0.67 & 0.65 & 0.96 & 0.97 & \\
\hline
\end{tabular}


Tablo 2. Türk Turizminde Ekonomik Değişkenlere Göre Etkinlik Skorları

\begin{tabular}{|c|c|c|c|c|c|c|c|c|c|c|c|c|}
\hline \multirow[b]{2}{*}{ İLLER } & \multicolumn{11}{|c|}{ YILLAR } & \multirow{2}{*}{$\begin{array}{c}\text { Orta- } \\
\text { lama } \\
\text { etkin- } \\
\text { lik }\end{array}$} \\
\hline & 2005 & 2006 & 2007 & 2008 & 2009 & 2010 & 2011 & 2012 & 2013 & 2014 & 2015 & \\
\hline ADANA & 0.66 & 0.60 & 0.75 & 0.76 & 0.26 & 0.16 & 0.29 & 0.38 & 0.37 & 0.93 & 0.96 & 0.56 \\
\hline ADIYAMAN & 1.00 & 0.84 & 1.00 & 1.00 & 0.62 & 0.50 & 0.47 & 0.93 & 1.00 & 0.95 & 0.95 & 0.84 \\
\hline $\begin{array}{l}\text { AFYONKARAHI- } \\
\text { SAR }\end{array}$ & 0.17 & 0.18 & 0.60 & 0.58 & 0.54 & 0.71 & 0.60 & 0.82 & 0.42 & 0.89 & 1.00 & 0.59 \\
\hline AĞRI & 0.80 & 1.00 & 0.76 & 0.94 & 1.00 & 1.00 & 1.00 & 0.18 & 0.09 & 0.77 & 0.81 & 0.76 \\
\hline AKSARAY & 1.00 & 0.93 & 1.00 & 1.00 & 1.00 & 1.00 & 1.00 & 1.00 & 1.00 & 1.00 & 1.00 & 0.99 \\
\hline AMASYA & 0.25 & 0.58 & 0.76 & 0.85 & 0.14 & 0.40 & 0.39 & 0.35 & 0.10 & 0.97 & 0.90 & 0.52 \\
\hline ANKARA & 0.92 & 1.00 & 1.00 & 1.00 & 0.76 & 1.00 & 0.91 & 0.91 & 1.00 & 0.98 & 0.98 & 0.95 \\
\hline ANTALYA & 1.00 & 1.00 & 1.00 & 1.00 & 1.00 & 1.00 & 1.00 & 1.00 & 1.00 & 1.00 & 1.00 & 1.00 \\
\hline ARDAHAN & 0.69 & 0.63 & 1.00 & 1.00 & 1.00 & 1.00 & 1.00 & 1.00 & 1.00 & 1.00 & 1.00 & 0.94 \\
\hline ARTVIN & 1.00 & 1.00 & 1.00 & 1.00 & 0.95 & 0.84 & 0.63 & 0.97 & 0.18 & 0.93 & 1.00 & 0.86 \\
\hline AYDIN & 1.00 & 1.00 & 1.00 & 1.00 & 0.70 & 0.55 & 0.60 & 0.83 & 1.00 & 1.00 & 0.97 & 0.88 \\
\hline BALIKESIR & 1.00 & 0.84 & 0.89 & 1.00 & 0.86 & 0.65 & 0.73 & 1.00 & 0.41 & 0.94 & 0.92 & 0.84 \\
\hline BARTIN & 0.37 & 1.00 & 0.85 & 1.00 & 0.29 & 0.33 & 0.41 & 1.00 & 1.00 & 1.00 & 0.94 & 0.74 \\
\hline BATMAN & 0.78 & 0.91 & 0.74 & 0.76 & 0.56 & 0.47 & 0.83 & 0.34 & 0.61 & 0.93 & 0.95 & 0.72 \\
\hline BAYBURT & 1.00 & 1.00 & 1.00 & 0.76 & 0.56 & 0.47 & 0.83 & 0.34 & 0.61 & 1.00 & 1.00 & 0.78 \\
\hline BİLECIK & 1.00 & 1.00 & 0.58 & 0.69 & 0.69 & 1.00 & 1.00 & 1.00 & 0.38 & 1.00 & 1.00 & 0.85 \\
\hline BINGÖL & 0.15 & 0.16 & 1.00 & 1.00 & 0.13 & 0.04 & 0.05 & 0.10 & 0.05 & 0.84 & 1.00 & 0.41 \\
\hline вітLіS & 1.00 & 1.00 & 1.00 & 1.00 & 1.00 & 1.00 & 0.28 & 0.22 & 0.11 & 0.88 & 0.96 & 0.77 \\
\hline BOLU & 1.00 & 1.00 & 1.00 & 0.74 & 1.00 & 0.50 & 0.26 & 0.48 & 0.34 & 0.90 & 0.92 & 0.74 \\
\hline BURDUR & 1.00 & 1.00 & 1.00 & 1.00 & 0.04 & 0.26 & 0.23 & 0.40 & 0.02 & 0.80 & 0.86 & 0.60 \\
\hline BURSA & 0.50 & 1.00 & 0.73 & 0.99 & 0.24 & 0.27 & 0.37 & 0.51 & 0.58 & 0.89 & 0.93 & 0.64 \\
\hline ÇANAKKALE & 1.00 & 0.68 & 0.96 & 1.00 & 0.65 & 0.48 & 0.53 & 0.40 & 0.48 & 0.93 & 0.96 & 0.73 \\
\hline ÇANKIRI & 0.16 & 0.18 & 0.90 & 1.00 & 0.12 & 0.46 & 0.11 & 1.00 & 0.20 & 0.92 & 1.00 & 0.55 \\
\hline ÇORUM & 0.24 & 0.19 & 0.75 & 0.86 & 0.44 & 1.00 & 0.60 & 1.00 & 0.17 & 1.00 & 0.95 & 0.66 \\
\hline DENIZLII & 1.00 & 1.00 & 1.00 & 1.00 & 1.00 & 1.00 & 1.00 & 1.00 & 0.82 & 0.94 & 0.97 & 0.98 \\
\hline DIYARBAKIR & 1.00 & 0.23 & 1.00 & 0.91 & 0.29 & 1.00 & 0.35 & 0.27 & 0.20 & 0.97 & 1.00 & 0.66 \\
\hline DÜZCE & 0.74 & 0.21 & 0.82 & 0.86 & 1.00 & 0.94 & 1.00 & 0.97 & 0.23 & 0.98 & 1.00 & 0.80 \\
\hline EDIRNE & 1.00 & 1.00 & 0.92 & 0.85 & 0.40 & 0.34 & 0.41 & 1.00 & 0.28 & 1.00 & 0.96 & 0.74 \\
\hline ELAZIĞ & 0.03 & 0.22 & 0.74 & 0.75 & 0.08 & 0.08 & 0.09 & 0.92 & 0.61 & 0.91 & 1.00 & 0.49 \\
\hline ERZINCAN & 0.10 & 0.14 & 1.00 & 1.00 & 0.10 & 0.53 & 0.16 & 0.28 & 0.30 & 1.00 & 0.97 & 0.51 \\
\hline ERZURUM & 0.15 & 0.55 & 0.80 & 0.80 & 0.24 & 0.22 & 0.93 & 1.00 & 0.16 & 0.88 & 0.97 & 0.61 \\
\hline ESKiŞEHIR & 0.69 & 0.21 & 0.74 & 0.91 & 0.37 & 0.35 & 1.00 & 0.38 & 0.23 & 0.88 & 1.00 & 0.62 \\
\hline GAZIANTEP & 0.29 & 0.33 & 0.82 & 0.83 & 0.54 & 0.29 & 0.30 & 0.30 & 0.30 & 0.87 & 0.96 & 0.53 \\
\hline GIRESUN & 0.93 & 0.97 & 0.68 & 0.74 & 0.32 & 0.17 & 0.09 & 0.33 & 0.09 & 0.82 & 0.88 & 0.55 \\
\hline GÜMÜŞHANE & 0.12 & 0.15 & 1.00 & 1.00 & 0.45 & 0.03 & 0.46 & 1.00 & 0.29 & 1.00 & 1.00 & 0.59 \\
\hline HAKKARI & 1.00 & 1.00 & 0.74 & 0.75 & 0.79 & 0.57 & 1.00 & 1.00 & 0.29 & 0.95 & 0.92 & 0.82 \\
\hline HATAY & 0.34 & 0.83 & 1.00 & 0.88 & 0.16 & 0.15 & 0.20 & 0.19 & 0.55 & 0.96 & 0.97 & 0.57 \\
\hline IĞDIR & 1.00 & 1.00 & 0.95 & 0.83 & 1.00 & 1.00 & 1.00 & 1.00 & 1.00 & 1.00 & 1.00 & 0.98 \\
\hline ISPARTA & 0.14 & 0.54 & 0.99 & 1.00 & 0.22 & 0.24 & 0.81 & 1.00 & 0.12 & 0.90 & 0.95 & 0.63 \\
\hline IÇEL-MERSIN & 1.00 & 0.87 & 0.73 & 0.67 & 0.26 & 0.17 & 0.23 & 0.26 & 0.25 & 0.85 & 0.96 & 0.57 \\
\hline ISTANBUL & 1.00 & 1.00 & 1.00 & 1.00 & 1.00 & 1.00 & 1.00 & 1.00 & 1.00 & 0.99 & 1.00 & 1.00 \\
\hline izmir & 0.45 & 0.80 & 1.00 & 1.00 & 1.00 & 0.81 & 0.85 & 0.61 & 0.56 & 0.93 & 0.97 & 0.82 \\
\hline $\begin{array}{l}\text { KAHRAMANMA- } \\
\text { RAŞ }\end{array}$ & 0.26 & 0.32 & 0.72 & 1.00 & 0.05 & 0.74 & 0.06 & 0.35 & 0.10 & 0.82 & 0.90 & 0.48 \\
\hline
\end{tabular}


Eskişehir Osmangazi Üniversitesi IïBF Dergisi

\begin{tabular}{|c|c|c|c|c|c|c|c|c|c|c|c|c|}
\hline \multirow[b]{2}{*}{ İLLER } & \multicolumn{11}{|c|}{ YILLAR } & \multirow{2}{*}{$\begin{array}{c}\text { Orta- } \\
\text { lama } \\
\text { etkin- } \\
\text { lik }\end{array}$} \\
\hline & 2005 & 2006 & 2007 & 2008 & 2009 & 2010 & 2011 & 2012 & 2013 & 2014 & 2015 & \\
\hline KARABÜK & 1.00 & 1.00 & 1.00 & 1.00 & 1.00 & 1.00 & 1.00 & 1.00 & 0.16 & 0.93 & 0.89 & 0.91 \\
\hline KARAMAN & 0.12 & 0.55 & 1.00 & 1.00 & 0.54 & 0.28 & 0.39 & 1.00 & 0.13 & 1.00 & 1.00 & 0.64 \\
\hline KARS & 0.10 & 0.22 & 0.82 & 1.00 & 0.54 & 0.73 & 0.15 & 1.00 & 0.84 & 0.94 & 0.95 & 0.66 \\
\hline KASTAMONU & 0.63 & 0.80 & 0.99 & 0.62 & 0.52 & 0.48 & 0.30 & 0.86 & 0.12 & 1.00 & 1.00 & 0.67 \\
\hline KAYSERi & 0.22 & 0.85 & 0.76 & 0.75 & 0.19 & 0.18 & 0.43 & 0.78 & 0.19 & 0.90 & 1.00 & 0.57 \\
\hline KIRIKKALE & 0.07 & 0.03 & 0.44 & 1.00 & 0.03 & 0.02 & 0.00 & 0.12 & 0.03 & 0.82 & 1.00 & 0.32 \\
\hline KIRKLARELI & 0.30 & 0.28 & 0.75 & 0.58 & 0.15 & 0.60 & 0.10 & 0.24 & 0.09 & 0.84 & 0.89 & 0.44 \\
\hline KIRŞEHIR & 0.86 & 1.00 & 0.79 & 0.87 & 0.61 & 0.05 & 0.06 & 0.33 & 0.98 & 1.00 & 1.00 & 0.69 \\
\hline KiLis & 0.86 & 1.00 & 1.00 & 1.00 & 1.00 & 1.00 & 1.00 & 1.00 & 0.98 & 1.00 & 1.00 & 0.99 \\
\hline KOCAELI & 0.17 & 0.60 & 0.54 & 0.54 & 0.36 & 0.34 & 0.36 & 0.39 & 0.26 & 0.90 & 0.93 & 0.49 \\
\hline KONYA & 0.53 & 0.26 & 1.00 & 0.97 & 0.33 & 0.47 & 0.30 & 1.00 & 0.39 & 0.87 & 0.91 & 0.64 \\
\hline KÜTAHYA & 0.16 & 0.19 & 0.78 & 0.82 & 0.18 & 0.98 & 0.95 & 1.00 & 0.63 & 0.95 & 0.97 & 0.69 \\
\hline MALATYA & 0.57 & 0.40 & 0.77 & 0.74 & 0.12 & 0.14 & 0.19 & 0.24 & 0.11 & 0.85 & 0.92 & 0.46 \\
\hline MANISA & 0.14 & 0.39 & 0.70 & 0.81 & 0.10 & 0.56 & 1.00 & 1.00 & 0.12 & 0.86 & 0.98 & 0.60 \\
\hline MARDIN & 0.18 & 0.62 & 1.00 & 0.81 & 0.43 & 0.49 & 0.48 & 0.49 & 0.67 & 0.99 & 0.99 & 0.65 \\
\hline MUĞLA & 1.00 & 1.00 & 0.95 & 1.00 & 0.94 & 0.80 & 0.76 & 0.62 & 1.00 & 1.00 & 1.00 & 0.91 \\
\hline MUŞ & 0.65 & 0.89 & 0.83 & 0.94 & 0.53 & 0.29 & 0.08 & 1.00 & 0.56 & 0.92 & 0.87 & 0.69 \\
\hline NEVŞEHIR & 1.00 & 1.00 & 1.00 & 1.00 & 1.00 & 1.00 & 1.00 & 1.00 & 1.00 & 1.00 & 1.00 & 1.00 \\
\hline NiĞDE & 0.01 & 0.32 & 1.00 & 0.72 & 0.16 & 0.15 & 0.14 & 0.64 & 0.08 & 0.79 & 0.95 & 0.45 \\
\hline ORDU & 0.81 & 1.00 & 0.97 & 0.96 & 0.48 & 0.47 & 0.59 & 1.00 & 0.22 & 0.90 & 1.00 & 0.76 \\
\hline OSMANIYE & 0.15 & 0.07 & 0.97 & 0.98 & 0.01 & 0.08 & 0.03 & 0.11 & 0.04 & 0.80 & 0.93 & 0.38 \\
\hline RizE & 1.00 & 0.78 & 1.00 & 1.00 & 0.63 & 0.29 & 0.10 & 0.13 & 0.12 & 1.00 & 0.96 & 0.64 \\
\hline SAKARYA & 0.07 & 0.41 & 0.87 & 1.00 & 0.20 & 0.03 & 0.41 & 0.38 & 0.16 & 0.87 & 0.98 & 0.49 \\
\hline SAMSUN & 0.26 & 0.28 & 0.79 & 0.90 & 0.08 & 0.15 & 0.10 & 0.21 & 0.13 & 1.00 & 0.90 & 0.44 \\
\hline SiiRT & 0.26 & 0.28 & 0.79 & 0.90 & 0.08 & 0.15 & 0.10 & 0.21 & 0.13 & 0.82 & 0.82 & 0.41 \\
\hline SINOP & 0.08 & 0.02 & 1.00 & 1.00 & 0.09 & 0.16 & 0.22 & 0.44 & 0.07 & 1.00 & 0.92 & 0.46 \\
\hline SIVAS & 0.76 & 0.33 & 0.69 & 0.67 & 0.32 & 0.27 & 0.44 & 0.43 & 0.07 & 0.81 & 0.94 & 0.52 \\
\hline ŞIRNAK & 0.99 & 0.74 & 1.00 & 1.00 & 1.00 & 1.00 & 0.54 & 1.00 & 1.00 & 1.00 & 1.00 & 0.93 \\
\hline TEKIRDAĞ & 0.53 & 0.07 & 0.76 & 0.55 & 0.24 & 0.20 & 0.25 & 0.51 & 0.18 & 1.00 & 1.00 & 0.48 \\
\hline TOKAT & 0.12 & 0.55 & 1.00 & 1.00 & 0.20 & 0.20 & 1.00 & 0.40 & 0.07 & 0.82 & 0.94 & 0.57 \\
\hline TRABZON & 0.67 & 0.38 & 0.90 & 0.84 & 0.50 & 0.48 & 0.21 & 0.30 & 0.20 & 0.89 & 0.97 & 0.58 \\
\hline TUNCELI & 1.00 & 0.20 & 0.67 & 1.00 & 0.07 & 0.06 & 1.00 & 1.00 & 1.00 & 1.00 & 1.00 & 0.73 \\
\hline URFA & 0.11 & 0.07 & 1.00 & 0.90 & 0.10 & 0.20 & 0.43 & 1.00 & 0.92 & 0.99 & 1.00 & 0.61 \\
\hline UŞAK & 1.00 & 0.97 & 0.88 & 1.00 & 0.74 & 0.56 & 1.00 & 0.58 & 0.06 & 0.97 & 1.00 & 0.80 \\
\hline VAN & 0.49 & 1.00 & 0.87 & 0.88 & 0.46 & 0.26 & 0.33 & 0.20 & 0.17 & 0.86 & 0.87 & 0.58 \\
\hline YALOVA & 1.00 & 1.00 & 1.00 & 0.71 & 1.00 & 1.00 & 1.00 & 1.00 & 1.00 & 1.00 & 1.00 & 0.97 \\
\hline YOZGAT & 0.57 & 0.56 & 1.00 & 1.00 & 0.34 & 0.32 & 0.73 & 0.41 & 0.12 & 0.86 & 1.00 & 0.63 \\
\hline ZONGULDAK & 0.58 & 0.33 & 0.72 & 0.69 & 0.22 & 0.21 & 0.23 & 1.00 & 1.00 & 1.00 & 1.00 & 0.64 \\
\hline $\begin{array}{l}\text { Etkin olan il yüz- } \\
\text { desi }\end{array}$ & 0.32 & 0.31 & 0.41 & 0.44 & 0.20 & 0.21 & 0.24 & 0.38 & 0.19 & 0.32 & 0.40 & \\
\hline $\begin{array}{l}\text { Ortalama etkin- } \\
\text { lik }\end{array}$ & 0.59 & 0.62 & 0.88 & 0.89 & 0.49 & 0.50 & 0.52 & 0.65 & 0.43 & 0.93 & 0.96 & \\
\hline
\end{tabular}

